\title{
Bile acid effects are mediated by ATP release and purinergic signalling in exocrine pancreatic cells
}

\author{
Justyna M. Kowal ${ }^{1}$, Kristian A. Haanes ${ }^{1,2}$, Nynne M. Christensen ${ }^{1}$ and Ivana Novak ${ }^{1 *}$ (D)
}

\begin{abstract}
Background: In many cells, bile acids (BAs) have a multitude of effects, some of which may be mediated by specific receptors such the TGR5 or FXR receptors. In pancreas systemic BAs, as well as intra-ductal BAs from bile reflux, can affect pancreatic secretion. Extracellular ATP and purinergic signalling are other important regulators of similar secretory mechanisms in pancreas. The aim of our study was to elucidate whether there is interplay between ATP and BA signalling.

Results: Here we show that CDCA (chenodeoxycholic acid) caused fast and concentration-dependent ATP release from acini (AR42J) and duct cells (Capan-1). Taurine and glycine conjugated forms of CDCA had smaller effects on ATP release in Capan-1 cells. In duct monolayers, CDCA stimulated ATP release mainly from the luminal membrane; the releasing mechanisms involved both vesicular and non-vesicular secretion pathways. Duct cells were not depleted of intracellular ATP with CDCA, but acinar cells lost some ATP, as detected by several methods including ATP sensor AT1.03 ${ }^{\text {YEMK }}$. In duct cells, CDCA caused reversible increase in the intracellular $\mathrm{Ca}^{2+}$ concentration $\left[\mathrm{Ca}^{2+}\right]_{\text {i, }}$, which could be significantly inhibited by antagonists of purinergic receptors. The TGR5 receptor, expressed on the luminal side of pancreatic ducts, was not involved in ATP release and $\mathrm{Ca}^{2+}$ signals, but could stimulate $\mathrm{Na}^{+} / \mathrm{Ca}^{2+}$ exchange in some conditions.
\end{abstract}

Conclusions: CDCA evokes significant ATP release that can stimulate purinergic receptors, which in turn increase $\left[\mathrm{Ca}^{2+}\right]_{i}$. The TGR5 receptor is not involved in these processes but can play a protective role at high intracellular $\mathrm{Ca}^{2+}$ conditions. We propose that purinergic signalling could be taken into consideration in other cells/organs, and thereby potentially explain some of the multifaceted effects of BAs.

Keywords: ATP release, P2 receptors, Bile acids, CDCA, TGR5, FXR, $\mathrm{Ca}^{2+}$, Pancreas, ATP sensor, AT1.03 ${ }^{\text {YEMK }}$, FLIM-FRET

\section{Lay abstract}

In recent years there has been a growing interest for the role of bile acids as signalling molecules in many cells/organs. Several types of bile acids receptors have been identified, but some modulatory functions of bile acids remain unexplained. Here, we show that bile acids, in particular chenodeoxycholic acid, causes significant release of ATP from exocrine pancreatic cells. Extracellular ATP can then via purinergic receptors regulate or co-regulate epithelial functions, such as pancreatic duct secretion, which is important for normal digestive processes. Our study brings novel

\footnotetext{
* Correspondence: inovak@bio.ku.dk

'Department of Biology, Section for Cell Biology and Physiology, August Krogh Building, University of Copenhagen, Universitetsparken 13, DK-2100 Copenhagen, Denmark

Full list of author information is available at the end of the article
}

insights into regulation of pancreas functions. Moreover, we propose that purinergic signalling should be taken into consideration in other cells/organ types, as it could potentially explain some of the multifaceted effects of bile acids.

\section{Background}

Bile acids (BAs) are natural amphiphilic metabolites originating from cholesterol degradation. The main human primary bile acids are chenodeoxycholic acid (CDCA) and cholic acid (CA), which can be conjugated with glycine and taurine to form bile salts. The role of bile acids as signalling molecules and as targets for drug development gained interest during the last years, and several bile acid receptors were discovered, including the nuclear farnesoid receptor (FXR) and the membrane receptor TGR5 (GPBAR1) [1-4]. TGR5 is expressed in many cell types 
and regulates a variety of functions. For example, TGR5 modulates liver function, glucose metabolism and insulin sensitivity, and immune responses [4-7]. In several epithelia such as colon, respiratory epithelia and bile ducts, BAs regulate ion transport, at least partly via TGR5 or FXR receptors [8-10]. For example, in bile ducts, TGR5 stimulates biliary $\mathrm{HCO}_{3}^{-}$and fluid secretion [11-14].

In pancreas, BAs have multiple effects. In the endocrine pancreas, tauroursodeoxycholate has a protective role on pancreatic islets as it decreases apoptosis and stimulates insulin secretion after stress conditions [15]. It is reported that BAs can stimulate both FXR and TGR5 receptors in mouse $\beta$-cells and induce fast insulin secretion [16, 17]. Furthermore, there is TGR5-dependent stimulation of glucagon-like-peptide-1 (GLP-1) release from enterocytes [18], and then systemic GLP-1 increases insulin secretion from $\beta$-cells [19]. In exocrine pancreas, BAs can exert effects on several levels, as they can reach pancreas not only systemically, but also via reflux of bile into pancreatic ducts. Pancreatic acini express BA transporters [20] and some BAs at low concentrations can activate $\mathrm{Ca}^{2+}$-independent cation currents [21]. At high concentrations BAs can evoke cytotoxicaly high intracellular $\mathrm{Ca}^{2+}$ concentrations, $\left[\mathrm{Ca}^{2+}\right]_{\mathrm{i}}$, in pancreatic acini. This is due to inhibition of the sacro/ endoplasmatic reticulum $\mathrm{Ca}^{2+}$-ATPases (SERCA), release of $\mathrm{Ca}^{2+}$ from ER and acidic stores and granules, increased $\mathrm{Ca}^{2+}$ influx, and acini show cellular acidosis, enzyme activation and mitochondrial malfunction, which can eventually lead to development of (biliary) acute pancreatitis [20, 22-24]. In one study, TGR5/GPBAR1 receptor knockout mice had less severe pancreatitis after infusion of BAs [25]. For pancreatic ducts, it has been proposed that BAs can stimulate duct secretion and they can tolerate higher BA concentrations [26-28]. Several studies show that BAs stimulate $\mathrm{Cl}^{-}$and $\mathrm{K}^{+}$channels; where the later have been identified as large conductance $\mathrm{Ca}^{2+}$-activated $\mathrm{K}^{+}$channels $\left(\mathrm{BK}, \mathrm{K}_{\mathrm{Ca}} 1.1\right)$, but identity of $\mathrm{Cl}^{-}$channels is not clear $[26,29,30]$.

Another important regulatory system in pancreatic ducts is the purinergic signalling. Extracellular ATP can, via a number of $\mathrm{P} 2$ receptors that stimulate $\mathrm{Ca}^{2+}$ signalling, regulate $\mathrm{Cl}^{-}$and $\mathrm{K}^{+}$channels and acid/base transporters and thereby modulate $\mathrm{HCO}_{3}^{-}$and fluid secretion [31,32]. Until now it has not been investigated whether pancreatic ducts release ATP, however, it is well established that ATP is released from pancreatic acini, which store ATP in zymogen granules, where it is accumulated by the Vesicular NUcleotide Transporter (VNUT, SLC17A9) [33]. Acinar ATP is released by exocytosis into the duct lumen in response to cholinergic or hormonal stimulation [34, 35]. In various other cells, ATP release can occur also via ion channels/transporters, such as maxi-anion channels, connexins, pannexins with/ without P2X7 receptors [36, 37].
Considering that BAs and purinergic signalling appear to have similar paracrine effects on ion and fluid transport in exocrine pancreas, we hypothesized whether there was any interaction between these two intra-ductal regulatory systems. Therefore, we designed a study to test whether BAs, i.e., chenodeoxycholic acid (CDCA) and its glycine and taurine conjugated forms (GCDCA and TCDCA) can affect ATP release, and whether CDCA also influence intracellular ATP levels. A further aim was to elucidate whether BA signalling involves TGR5 or FXR receptors in the ATP release process and/or P2 receptors and downstream $\mathrm{Ca}^{2+}$ signalling. For this purpose we used duct and acini models (Capan-1 and AR42J cells), live cell luminescence assay for extracellular ATP, intracellular ATP sensors, AT1.03 ${ }^{\mathrm{YEMK}}$, and $\left[\mathrm{Ca}^{2+}\right]_{\text {i. imaging. Our study }}$ shows that CDCA indeed caused a very fast release of ATP from exocrine pancreatic cells via both nonexocytotic and vesicular pathways. Furthermore, a significant part of the CDCA effect on $\mathrm{Ca}^{2+}$ signalling is mediated via purinergic signalling. We also demonstrate the presence of the TGR5 and FXR receptors in human pancreatic ducts and show that TGR5 receptor can prevent intracellular $\mathrm{Ca}^{2+}$ overloads possibly by stimulation of the $\mathrm{Na}^{+} / \mathrm{Ca}^{2+}$ exchanger.

\section{Results}

\section{CDCA but not GCDCA and TCDCA stimulates high ATP} release from pancreatic cells

ATP release on the whole organ level is difficult to detect due to action of membrane-bound and soluble nucleotidases $[35,38]$. Therefore, ATP release and autocrine/paracrine signalling is usually studied on isolated cells or cell lines. In the first series of experiments we investigated the effect of several bile acids: GCDCA (glycochenodeoxycholic acid); TCDCA (taurochenodeoxycholic acid); and CDCA (chenodeoxycholic acid) on ATP release from Capan-1 cells, which are a model of pancreatic ducts. Time resolved luminescence recordings revealed that $0.3 \mathrm{mM}$ of GCDCA and TCDCA had minor effects on ATP release from these cells (Fig. 1 a-b). At higher concentrations (1 mM) GCDCA evoked significant but small increase in extracellular ATP, ATP ${ }_{\mathrm{e}}$, by $4.2 \pm 0.8$ $\mathrm{nM}(\mathrm{n}=4)$ above the basal level. TCDCA $(1 \mathrm{mM})$ had no effect on ATP release. In contrast to GCDCA and TCDCA, CDCA (0.3 mM) caused a fast and substantial ATP release in Capan-1 cells (Fig. 1c). Therefore, we investigated the effect of CDCA concentrations on ATP release from Capan-1 (Fig. 1d). Furthermore, we investigated the effect of CDCA on AR42J cells, which are a model for pancreatic acinar cells (Fig. 1 e, f). Fig. 1 c-f shows that the duct and acinar cells released ATP in a concentration-dependent manner in a narrow range from 0.1 to $1 \mathrm{mM} \mathrm{CDCA}$, and $\mathrm{EC}_{50}$ values are $0.43 \mathrm{mM}$ and $0.44 \mathrm{mM}$ for Capan-1 and AR42J cells, respectively. The 

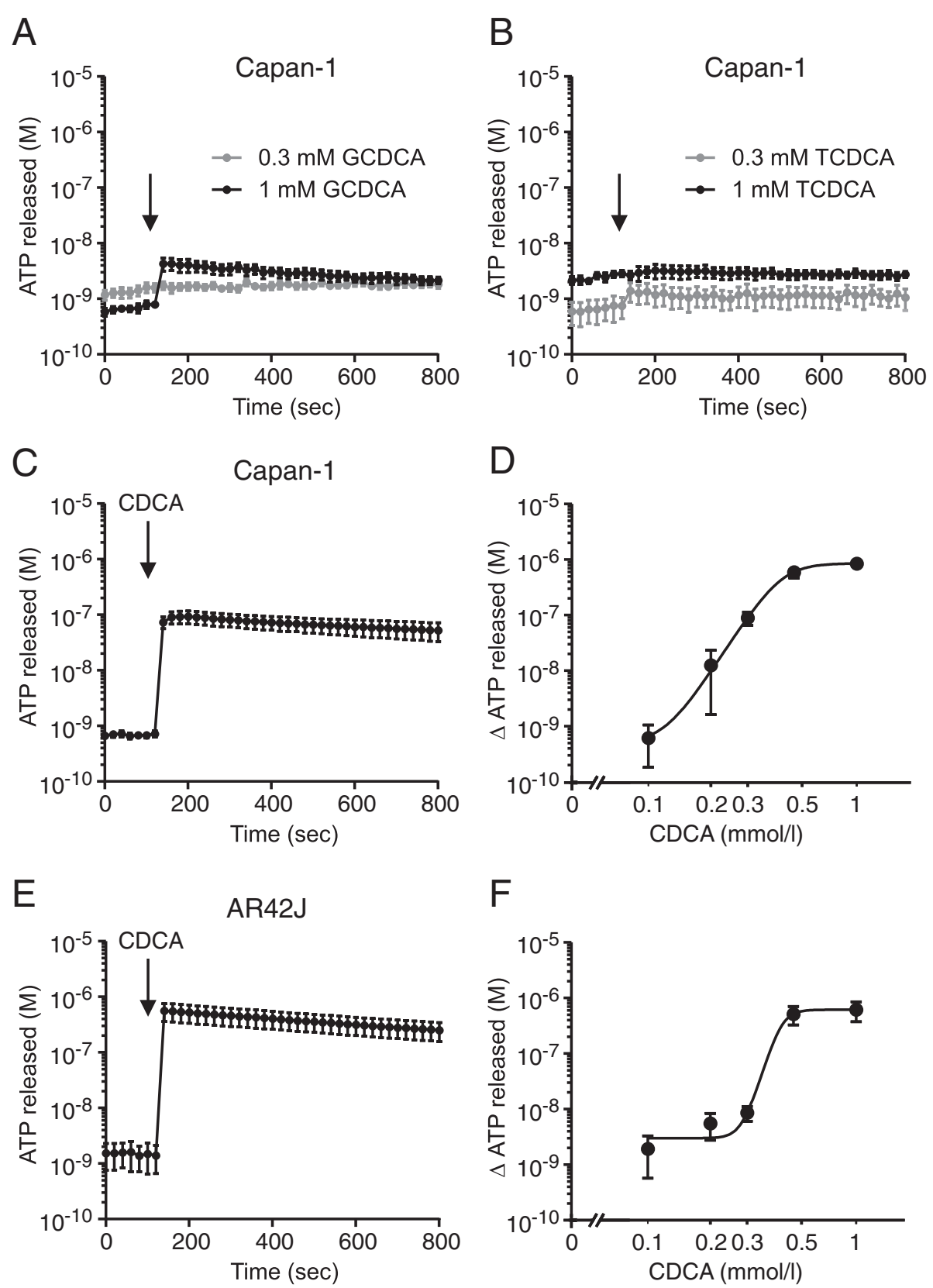

Fig. 1 CDCA induced ATP release from exocrine pancreatic cells. The time-course of ATP release from Capan-1 cells in response to 0.3 and $1 \mathrm{mM}$ of (a) GCDCA and (b) TCDCA $(n=4,4)$. The time-course of ATP release from (c) Capan-1 and (e) AR42J after stimulation with 0.3 and 0.5 mM CDCA, respectively $(n=6,5)$. Dose-dependent release of ATP from (d) Capan-1 and ( $f$ ) AR42J cells in response to CDCA $(n=5,6)$. The EC 50 values of ATP release from AR42J and Capan-1 are $0.44 \mathrm{mM}\left(\mathrm{pEC}_{50}=3.36 \pm 0.03\right)$ and $0.43 \mathrm{mM}(\mathrm{pEC} 503.36 \pm 0.04)(n=5,6)$ respectively in the range of $0.1-1 \mathrm{mM}$ CDCA. Y-axis shows ATP concentrations, which were corrected for $10^{6}$ cells per $1 \mathrm{ml}$ (see Methods). Data shown as mean values \pm SEM. Arrows indicate addition of stimulants

peak/maximum ATP release observed after stimulation with $1 \mathrm{mM}$ CDCA was $848 \pm 16 \mathrm{nM}(\mathrm{n}=6)$ for Capan-1 and $614 \pm 79 \mathrm{nM}(\mathrm{n}=5)$ for AR42J cells. These data show that CDCA can increase extracellular ATP concentrations by a factor of 100-1000 above the baseline. In all the following experiments, Capan-1 cells were stimulated with $0.3 \mathrm{mM} \mathrm{CDCA}$ and AR42J cells with $0.5 \mathrm{mM}$ CDCA.
Since Capan-1 cells are a model of human pancreatic duct epithelium, it was relevant to investigate whether ATP release is polarized, i.e., whether it occurs preferentially across the luminal or the basolateral membrane. Capan-1 cells were cultured as polarized monolayers, and CDCA was administered luminally or basolaterally. After the luminal stimulation with $0.3 \mathrm{mM}$ CDCA (Fig. 2a), 


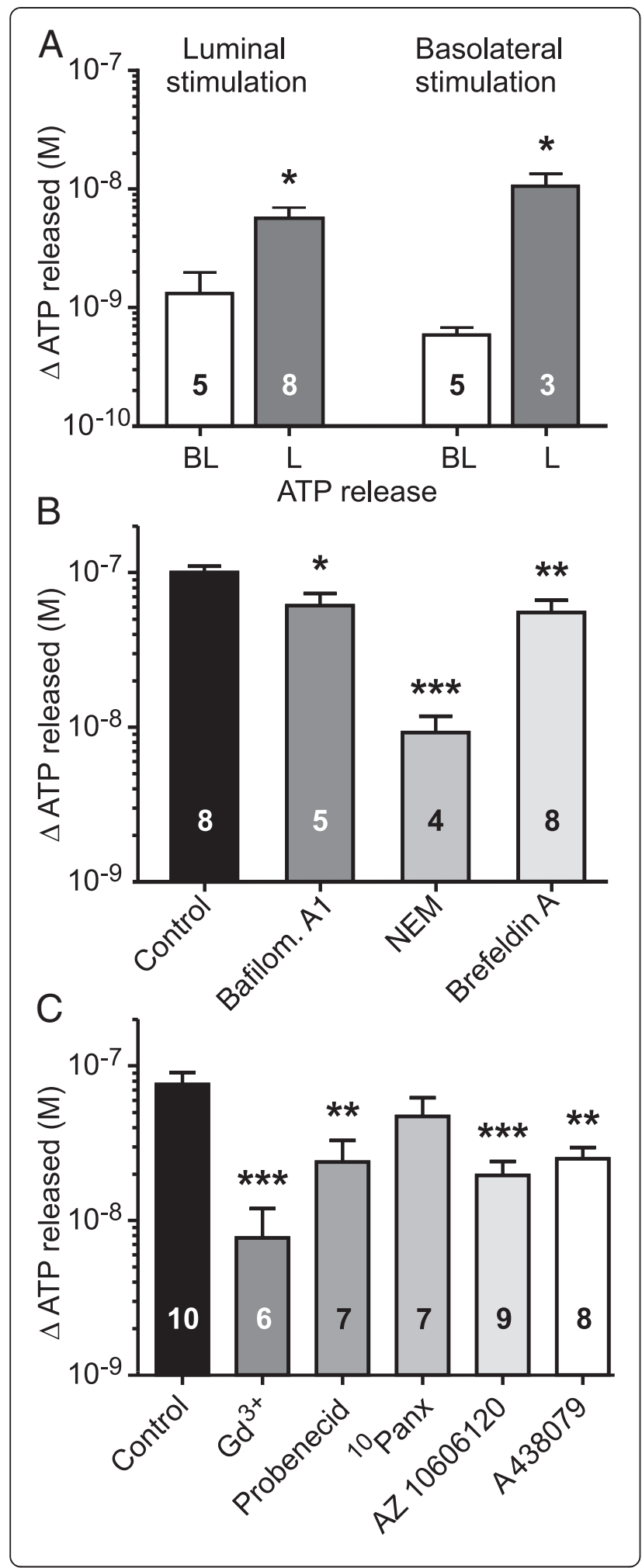

Fig. 2 Sidedness of ATP release and the effect of vesicular and non-vesicular inhibitors on ATP release pathways. a Mean values of ATP released across basolateral (BL) and luminal $(\mathrm{L})$ sides from Capan-1 cells after 1 min of apical or serosal stimulation with 0.3 mM CDCA. $\mathbf{b}$ Inhibitors of vesicular transport decreased ATP release from Capan-1 cells in response to $0.3 \mathrm{mM}$ CDCA. Cells were incubated with vacuolar-type $\mathrm{H}^{+}$-ATPase inhibitor (bafilomycin $\mathrm{A} 1,1 \mu \mathrm{M} ; \mathrm{n}=5$ ), vesicle fusion inhibitor $\mathrm{N}$-Ethylmaleimide (NEM, $250 \mu \mathrm{M}, \mathrm{n}=4)$ and brefeldin A $(5 \mu \mathrm{g} / \mathrm{ml} ; \mathrm{n}=8)$. c Influence of the non-vesicular transport inhibitors: gadolinium chloride $\left(\mathrm{Gd}^{3+}, 50 \mu \mathrm{M} ; \mathrm{n}=6\right)$, probenecid $(500 \mu \mathrm{M} ; \mathrm{n}=7),{ }^{10} \mathrm{Pan} \mathrm{x}$ - mimetic pannexin peptide $(100 \mu \mathrm{M} ; \mathrm{n}=7)$, as well as P2X7 receptor inhibitors AZ10606120 (10 $\mu \mathrm{M} ; \mathrm{n}=9)$ and A438079 (10 $\mu \mathrm{M} ; \mathrm{n}=7)$ on CDCA-induced ATP release from Capan-1 cells is shown. Results are given as mean net values \pm SEM. ${ }^{*}=P<0.05$, ${ }^{* *}=P<0.01,{ }^{* * *}=P<0.001$

there was significantly higher ATP release from the luminal side $(5.7 \pm 1.3 \mathrm{nM}, \mathrm{n}=8)$ compared to the basolateral side $(1.3 \pm 0.7 \mathrm{nM}, \mathrm{n}=5)$. Interestingly, a similar high luminal ATP release was observed when monolayers were stimulated with basolateral CDCA (Fig. 2a). ATP released across the luminal side was $10.5 \pm 2.9 \mathrm{nM}$ $(n=3)$ compared to the basolateral side $0.6 \pm 0.03 \mathrm{nM}$ $(\mathrm{n}=5)$. Notably, these ATP values made in offline analysis of samples were lower than in online measurements, most likely due to different sampling volumes and ATP hydrolysis by ecto-nucleotidases [39, 40].

\section{CDCA induces ATP release via multiple pathways}

In order to identify the pathways involved in CDCAinduced ATP release, Capan-1 cells were incubated with vesicular and non-vesicular transport inhibitors. Fig. $2 \mathrm{~b}$ shows that CDCA caused high ATP release of $100 \pm 10$ $\mathrm{nM}(\mathrm{n}=8)$, and after incubation with bafilomycin A1, an inhibitor for vacuolar-type $\mathrm{H}^{+}$-ATPase, ATP release was significantly reduced to $61 \pm 12 \mathrm{nM}(\mathrm{n}=5)$. Inhibition of CDCA-evoked vesicular ATP release was also observed in the presence of N-Ethylmaleimide, an inhibitor of vesicle fusion, which markedly supressed ATP release to $9 \pm 3 \mathrm{nM}(\mathrm{n}=4)$. In addition, reducing vesicular transport from ER to Golgi by brefeldin A also decreased the ATP release to $55 \pm 11 \mathrm{nM}(\mathrm{n}=8)$. In another series of experiments, we tested the effect of non-vesicular transport inhibitors (Fig. 2c). Data presented in Fig. 2c, show that $\mathrm{Gd}^{3+}$, which inhibits pannexin and connexin hemichannels in addition to maxi anion channels, markedly inhibited CDCA-induced ATP release to $8 \pm 4 \mathrm{nM}(\mathrm{n}=6)$ compared to control of $76 \pm 15 \mathrm{nM}(\mathrm{n}=10)$. When cells were treated with probenecid, there was a significant decrease in ATP release to $24 \pm 9 \mathrm{nM}(\mathrm{n}=7)$. The pannexin-1 inhibitor, ${ }^{10} \mathrm{Panx}$, tended to decrease ATP release to $47 \pm 15 \mathrm{nM}(\mathrm{n}=7)$, but no statistical significance was reached. Two P2X7 receptor antagonists significantly inhibited the ATP release to $19 \pm 5 \mathrm{nM}$ $(\mathrm{AZ10606120}, \mathrm{n}=9)$ and $25 \pm 5 \mathrm{nM}(\mathrm{A} 438079, \mathrm{n}=8)$. 
Taken together, present data indicate that both vesicular and non-vesicular mechanisms are involved in CDCAinduced ATP release from pancreatic epithelial cells.

\section{Effect of CDCA on intracellular ATP}

Since we observed that CDCA stimulated substantial ATP release from exocrine pancreatic cells, in the following experiments we investigated whether this was accompanied by a decrease of intracellular ATP concentrations, ATP $_{\mathrm{i}}$. We used the Magnesium Green (MgGreen), an indirect ATP sensor, as it increases in fluorescence when ATP concentrations decrease and the released $\mathrm{Mg}^{2+}$ can bind to the fluorophore. After CDCA stimulation, there was a fast and transient increase in the MgGreen F/F0 fluorescence ratio to $1.53 \pm 0.21$ in AR42J $(n=3)$, and then the ratio decreased but remained elevated by about 0.2 units above the basal value (Fig. 3a). Capan-1 cells also responded by a transient increase in F/F0 ratio to $1.34 \pm 0.08(\mathrm{n}=6)$, but after 300-400 s the signal recovered to pre-CDCA values (Fig. 3b). The transient changes in MgGreen fluorescence could have several explanations (see Discussion). Since we observed a tendency to partial depletion of ATP $\mathrm{A}_{\mathrm{i}}$ in AR42J cells after prolonged stimulation with CDCA (Fig. 3a), we used a more direct method employing one of the ATeam sensors developed by Imamura and colleagues [41].

AR42J cells were transfected with AT1.03 ${ }^{\text {YEMK }}$ and simultaneous images of YFP and CFP were used to build YFP/CFP ratio. Fig. 4a shows that there was a small decrease in the ratio with CDCA incubation, which indicates decreased FRET. In addition, in separate fluorescence lifetime imaging (FLIM) experiments we determined CFP fluorescence lifetime of AT1.03 ${ }^{\text {YEMK }}$ using the timecorrelated single-photon counting technique. The data were used to generate a lifetime map by fitting each point to a double exponential decay. $X^{2}$ values were lying around 0.9-1.1. The sensor had a uniform lifetime distribution within the cell cytoplasm (Fig. 4b). It is well established that CFP has bi-exponential decay and the reported lifetimes lie around 1.1-1.3 ns and 2.8-2.9 ns [42]. For untreated AR42J cells we found two lifetimes of $0.876 \pm$ $0.013 \mathrm{~ns}$ and $2.732 \pm 0.026 \mathrm{~ns}(\mathrm{n}=25)$. These lifetimes were shorter than the reported lifetime for CFP due to fact that the interacting donor lifetime is shortened by ATP binding and causing FRET in the AT1.03 ${ }^{\mathrm{YEMK}}$ sensor. After addition of CDCA the lifetimes increased to $0.950 \pm$ 0.018 and $2.815 \pm 0.033$ in the same experiments, indicating that there is less FRET, likely corresponding to less ATP within the cell.

The above $\operatorname{ATP}_{\mathrm{i}}$ measurement methods are dynamic, but difficult to calibrate in acinar cells. Therefore, we also used luciferin/luciferase assay to determine $\operatorname{ATP}_{\mathrm{i}}$. Cell membranes were permeabilized with digitonin after CDCA treatment and intracellular $\mathrm{ATP}_{\mathrm{i}}$ was quantified (Fig. 5a). ATP ${ }_{i}$ concentrations were measured at different
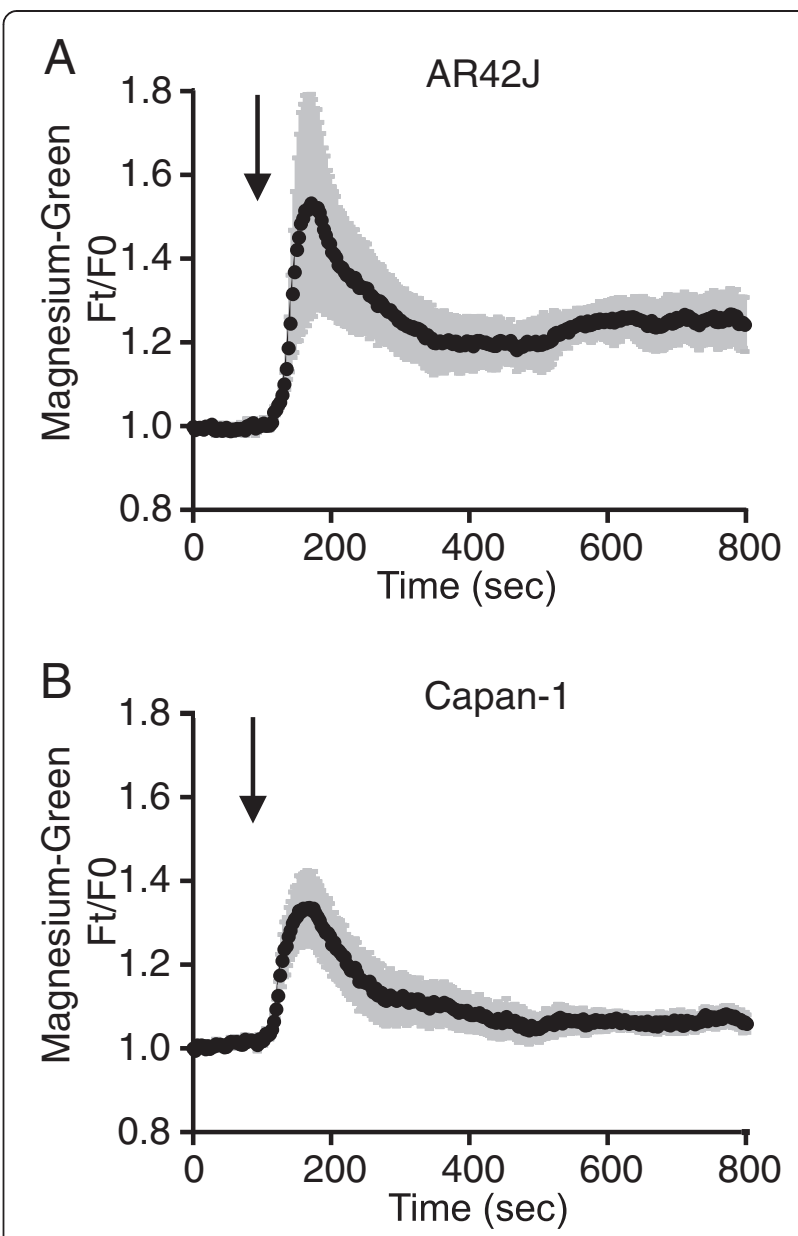

Fig. 3 CDCA effect on Magnesium Green fluorescence in AR42J and Capan-1. Effect of 0.5 and 0.3 mM CDCA on intracellular ATP (ATP $)$ changes in AR42J (a) $(n=3)$ and Capan-1 $(\mathbf{b})(n=4)$ cells. Cells were loaded with Magnesium Green indicator ( $5 \mu \mathrm{M}$ ) for $20 \mathrm{~min}$. Changes of ATP are given as ratios of fluorescence at time $t$ in relation to time $0\left(F_{t} / F_{0}\right)$, where the starting baseline is set to the 1 . Results are shown as mean values \pm SEM of 10 cells or group of acini per each individual experiment. Arrows indicate time of adding CDCA

time points (1 and $12 \mathrm{~min}$ ), correlating with the peak and plateau for MgGreen (Fig. 3). Additionally, the long-term effect was also determined by incubating the cells with CDCA for $24 \mathrm{~h}$. After stimulation with $0.3 \mathrm{mM}$ CDCA, Capan-1 released $68 \pm 26 \mathrm{nM}$ ATP to extracellular medium, which corresponds to a calculated decrease of $0.08 \pm 0.03 \mathrm{mM} \mathrm{ATP}_{\mathrm{i}}$ in a cell $(\mathrm{n}=8)$. Fig. $5 \mathrm{~b}$ shows that after incubation of duct cells for $1 \mathrm{~min}$ and $12 \mathrm{~min}$, the total content of remaining $\operatorname{ATP}_{\mathrm{i}}$ was not significantly changed and remained at $2.47 \pm 0.32 \mathrm{mM}$ calculated per cell; $(\mathrm{n}=8)$ and $2.22 \pm 0.5 \mathrm{mM}(\mathrm{n}=7)$ compared to their respect controls of $2.72 \pm 0.38 \mathrm{mM}$ and $2.46 \pm 0.45 \mathrm{mM}$ $(n=7)$. Furthermore, the long-term exposure of Capan-1 to $0.3 \mathrm{mM}$ CDCA did not cause significant changes in $\mathrm{ATP}_{\mathrm{i}}$ concentrations, i.e., $2.08 \pm 0.24 \mathrm{mM}$ compared to control $1.85 \pm 0.18 \mathrm{mM}(\mathrm{n}=10)$. For AR42J cells, 


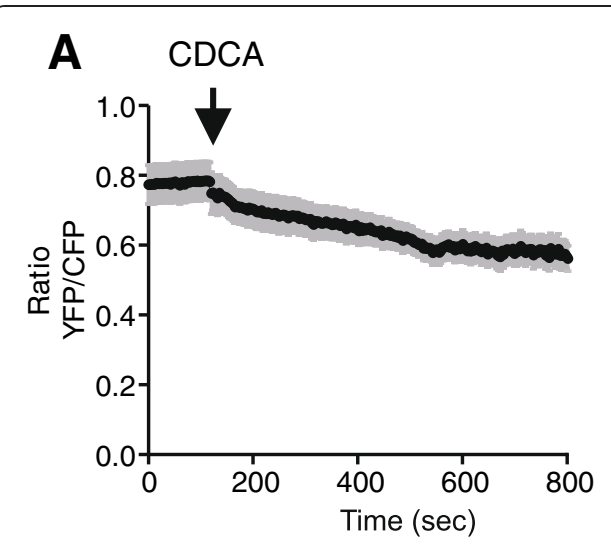

B Average
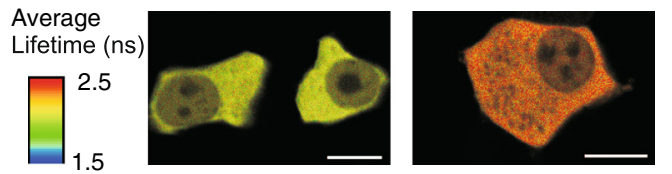

\begin{tabular}{|l|c|c|c|c|}
\hline & \multicolumn{2}{|c|}{ Before CDCA } & \multicolumn{2}{c|}{ After CDCA } \\
\hline Lifetime (ns) & $\mathrm{T} 1$ & $\mathrm{~T} 2$ & $\mathrm{~T}^{*}$ & T2 $^{*}$ \\
\hline Average & 0.876 & 2.732 & 0.950 & 2.815 \\
\hline SEM & 0.013 & 0.026 & 0.018 & 0.033 \\
\hline $\mathbf{n}$ & 25 & 25 & 25 & 25 \\
\hline
\end{tabular}

Fig. 4 Effect of CDCA on ATP sensor (AT1.03 ${ }^{\text {YEMK) }}$ in AR42J cells. a Effect of $0.5 \mathrm{mM}$ CDCA on FRET ratio of the ATP sensor in AR42J cells $(n=25)$. $\mathbf{b}$ Lifetime images of cells before and after treatment with CDCA. Images, where each pixel was analysed, are average of the two lifetime constants corrected for intensity scale. The insert table summarizes FLIM-FRET life constants T1 and T2 in 25 independent experiments. ${ }^{*} P=0.0001$ for $\mathrm{T} 1$ and $P=0.007$ for $\mathrm{T} 1$ and $\mathrm{T} 2$ comparison

stimulation with $0.5 \mathrm{mM}$ CDCA (Fig. 5c) caused ATP release of $358 \pm 52 \mathrm{nM}$ to extracellular medium, which corresponds to a calculated decrease of $0.68 \pm 0.1 \mathrm{mM}$ in the cell $(\mathrm{n}=5)$. Similar to the Capan-1 cells, we did not observe significant changes in remaining $\mathrm{ATP}_{\mathrm{i}}$ concentrations after $1 \mathrm{~min}(1.36 \pm 0.1 \mathrm{mM} ; \mathrm{n}=5)$. However, after $12 \mathrm{~min}$ there was a tendency, though not significant, of lower intracellular ATP levels $(0.68 \pm 0.06 \mathrm{mM} ; \mathrm{n}=5)$ with CDCA compared to their respective controls (1.12 \pm $0.01 \mathrm{mM}$ and $0.97 \pm 0.13 \mathrm{mM} ; \mathrm{n}=5$ ). Furthermore, after $24 \mathrm{~h}$ incubation of AR42J with $0.5 \mathrm{mM}$ CDCA, there was a significant decrease of ATP $_{i}$ to $0.66 \pm 0.06 \mathrm{mM}$ compared to the control $1.3 \pm 0.08 \mathrm{mM}(\mathrm{n}=10)$.

\section{CDCA-induced intracellular $\mathrm{Ca}^{2+}$ responses are inhibited by $\mathrm{P} 2$ receptor inhibitors}

Bile acids are reported to increase $\left[\mathrm{Ca}^{2+}\right]_{\mathrm{i}}$ in pancreatic cells, but it is not clear which receptors are involved (see Introduction). Since we observed that CDCA induced ATP release, we hypothesized that the intracellular $\mathrm{Ca}^{2+}$ responses could be due to effect of released ATP on P2 receptors, which are well established regulators of stimulated $\mathrm{Ca}^{2+}$ influx and/or $\mathrm{Ca}^{2+}$ release in pancreatic ducts. Therefore, $\left[\mathrm{Ca}^{2+}\right]_{\mathrm{i}}$ was monitored in Capan-1 cells in a chamber perfused with physiological solution containing CDCA followed by ATP (Fig. 6a,c). CDCA evoked a slow $\Delta\left[\mathrm{Ca}^{2+}\right]_{\mathrm{i}}$ increase $(180 \pm 24 \mathrm{nM}, \mathrm{n}=5)$. Similar slow and small responses to other BAs were also reported for pancreatic acinar cells and cholangiocytes [25, 43]. In contrast, infusion of ATP caused fast and markedly higher $\Delta\left[\mathrm{Ca}^{2+}\right]_{\mathrm{i}}$ increase $(772 \pm 173 \mathrm{nM}, \mathrm{n}=5)$. Further experiments were conducted without perfusion, in order to minimize mechanical stimulation and amount of inhibitors used. In standing bath CDCA evoked similar $\Delta\left[\mathrm{Ca}^{2+}\right]_{\mathrm{i}}$ response as in the perfused conditions, but the signal was delayed (Fig. 6b, d). Stimulation with ATP in the presence of CDCA, caused a lower but fast $\Delta\left[\mathrm{Ca}^{2+}\right]_{i}$ response $(302 \pm 47 n M, n=4)$, perhaps because P2 receptors were already desensitized by CDCA-induced ATP release as ATP was not washed away during perfusion. Therefore, for the following studies with P2R inhibitors, we conducted separate experiments for the ATP and CDCA stimuli.

Figure 7a-d shows that the P2R inhibitors markedly reduced the ATP-stimulated $\Delta\left[\mathrm{Ca}^{2+}\right]_{\mathrm{i}}$ response from $937 \pm$ $88 \mathrm{nM}(\mathrm{n}=11)$ to $232 \pm 47 \mathrm{nM}(\mathrm{n}=9)$. The antagonists also caused significant inhibition of CDCA stimulated $\Delta\left[\mathrm{Ca}^{2+}\right]_{\mathrm{i}}$ (from $217 \pm 54$ to $90 \pm 9 \mathrm{nM} ; \mathrm{n}=5$ ). These data indicate that the $\Delta\left[\mathrm{Ca}^{2+}\right]_{\mathrm{i}}$ response evoked by the bile acid could be a result of P2 receptor stimulation by CDCA-induced ATP release. Thapsigargin, the inhibitor of SERCA [44], was added at the end of the experiments to inhibit re-uptake of $\mathrm{Ca}^{2+}$ to intracellular stores. Thapsigargin induced a small $\Delta\left[\mathrm{Ca}^{2+}\right]_{i}$ increase after CDCA by $70 \pm 17 \mathrm{nM}(\mathrm{n}=5)$ but a large increase after ATP, i.e., $971 \pm 143 \mathrm{nM},(\mathrm{n}=6)$. P2R inhibitors did not have effect on intracellular $\mathrm{Ca}^{2+}$ response induced by thapsigargin after ATP (Fig. 7c). Interestingly, when thapsigargin was applied after CDCA in the presence of the P2R inhibitors (Fig. $7 \mathrm{~d}), \Delta\left[\mathrm{Ca}^{2+}\right]_{\mathrm{i}}$ was significantly higher $(270 \pm 35$ $n M, n=5)$.

\section{Expression of the TGR5 and FXR receptors in exocrine pancreatic cells}

It is not known whether TGR5 and FXR receptors are expressed in the human pancreatic ducts and could account for the effects seen in our study. Also from studies on animal pancreatic tissue, it is not certain whether TGR5 is expressed in ducts $[25,29]$. We therefore investigated TGR5 expression in AR42J and Capan-1 cells using RT-PCR and Western Blot. Fig. 8a, b shows that TGR5 is expressed in both cell lines. This observation was confirmed by immunostaining of the acinar cells and on a polarized monolayer of Capan-1 (Fig. 8c, d). In duct epithelium it appears that the receptor is localized mainly on the luminal membrane. Since TGR5 is expressed in pancreatic cells, we wanted to determine whether the receptor has any effect on ATP release and 


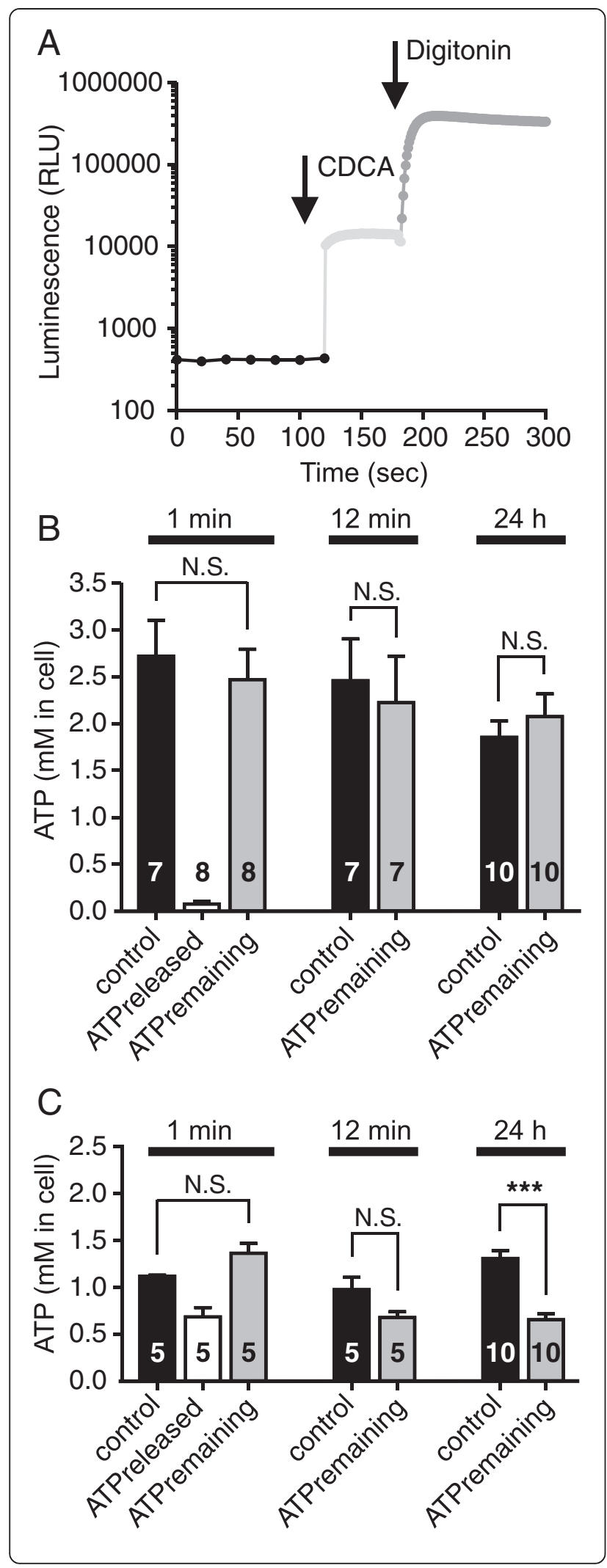

Fig. 5 The acute and chronic effects of CDCA on intracellular ATP concentration in AR42J and Capan-1 cells. a Original trace for luminometric measurements of ATP based on Capan-1 measurement. Baseline values were recorded every $20 \mathrm{~s}$ for $2 \mathrm{~min}$. Cells were then stimulated with $0.3 \mathrm{mM}$ (Capan-1) or $0.5 \mathrm{mM}$ (AR42J) with CDCA or with vehicle. Stimulated ATP release was recorded every $1 \mathrm{sec}$ for 1 min directly after addition of CDCA, or after 12 min or $24 \mathrm{~h}$ of incubation. Finally, cells were permeabilized with digitonin $(50 \mu \mathrm{M})$, added automatically using pump to release remaining ATP. Panel b and $\mathbf{c}$ show the values of released and remaining ATP in Capan-1 and AR42J cells, respectively. These values were calculated per cell after 1,12 min and $24 h(n=8,7,10$ and $n=5,5,10)$ of incubation with CDCA. Data are shown as mean values \pm SEM; ${ }^{* * *}=P<0.001$, N.S. - not significant

for this purpose we used GPBAR-A, a specific TGR5 receptor agonist that upon binding stimulates cAMP synthesis [45]. Using the luminescence method, we did not detect ATP release (Fig. 8e) from Capan-1 cells after stimulation with 3 or $30 \mu \mathrm{M}$ GPBAR-A.

In another series of experiments we investigated whether Capan-1 cells express the nuclear type of bile acid receptor, FXR, and whether its stimulation might induce ATP release. We indeed found the transcript for FXR in Capan-1 cells using RT-PCR (Fig. 8f). However, activation of the receptor with the specific agonist GW4064 (0.1 and $1 \mu \mathrm{M})$ did not cause significant ATP release (Fig. 8f). Based on these observations, we concluded that stimulation of BAs receptors TGR5 and FXR with specific pharmacological agonists does not induce ATP release from duct cells.

Above we observed that CDCA appeared to protect Capan-1 cells from thapsigargin effects (Fig. 7d, f). This could occur if, for example, CDCA stimulated SERCA (or protected the pumps from thapsigargin) or if CDCA stimulated alternative $\mathrm{Ca}^{2+}$ efflux pathways. Our hypothesis was that the TGR5 receptor could be involved in these effects and we tested this in the following experiments. First, intracellular $\mathrm{Ca}^{2+}$ stores were emptied by thapsigargin in low $\mathrm{Ca}^{2+}$ medium (Fig. 9a). Thereafter, extracellular $\mathrm{Ca}^{2+}$ was reintroduced, and since SERCA pumps were inhibited, $\left[\mathrm{Ca}^{2+}\right]_{\mathrm{i}}$ increased to very high levels in control cells. Notably, perfusion of the cells with CDCA caused a fast and marked reduction in $\left[\mathrm{Ca}^{2+}\right]_{\mathrm{i}}$ from $1253 \pm 117$ to $244 \pm 28 \mathrm{nM}$ (Fig. 9 a, b, $\mathrm{n}=3$ ). A similar response was observed with perfusion of GPBAR-A (Fig. 9a-b), which lowered the $\left[\mathrm{Ca}^{2+}\right]_{\mathrm{i}}$ from $1249 \pm 69$ $\mathrm{nM}$ to $647 \pm 71 \mathrm{nM}(\mathrm{n}=5)$.

In next experiments we addressed the question whether the lowering of $\left[\mathrm{Ca}^{2+}\right]_{\mathrm{i}}$ caused by CDCA could involve $\mathrm{Ca}^{2+}$ efflux via the $\mathrm{Na}^{+} / \mathrm{Ca}^{2+}$ exchanger (NCX), which is expressed in duct epithelia [46, 47]. Since CDCA evokes $\mathrm{Ca}^{2+}$ transients itself, we used, GPBAR-A, which showed no effect on $\mathrm{Ca}^{2+}$ responses when given alone (see Additional file 1: Figure S1). Capan-1 cells were 


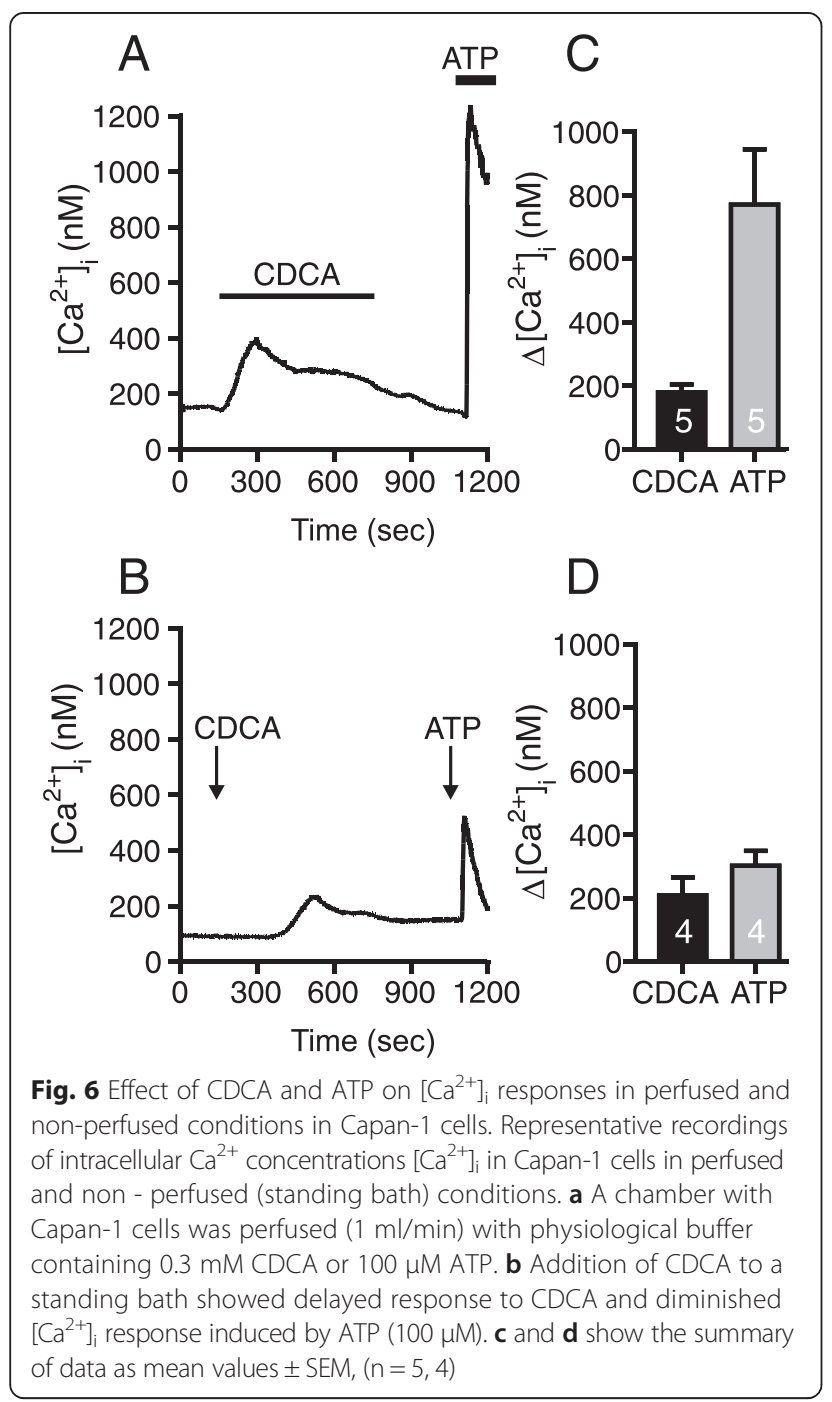

perfused with a buffer containing $5 \mathrm{mM} \mathrm{Na}{ }^{+}$, which favours $\mathrm{Ca}^{2+}$ influx via NCX as observed in Fig. 9c. This effect of low $\mathrm{Na}^{+}$on $\left[\mathrm{Ca}^{2+}\right]_{\mathrm{i}}$ was increased with GPBARA $(30 \mu \mathrm{M})$, which is consistent with TGR5 stimulation of NCX.

\section{Discussion}

The present study shows that some of the BA (i.e., CDCA) effects are due to stimulation of purinergic signalling. Firstly, acini and ducts (AR42J and Capan-1 cells) release substantial amounts of ATP in response to CDCA, and this process can be inhibited by several inhibitors of ATP release. Secondly, CDCA effects on intracellular $\mathrm{Ca}^{2+}$ could be significantly inhibited by P2 receptor antagonists, indicating cross-activation of the two signalling pathways. Furthermore, the TGR5 receptor affected intracellular $\mathrm{Ca}^{2+}$ indirectly by activating NCX. Below, we discuss these results and propose that interplay between BAs and purinergic signalling may be important in physiological regulation of pancreatic function.

In order to evaluate physiological or pathological effects of BAs, it is important to consider what BAs concentrations pancreas may encounter. In healthy human, plasma BAs concentrations are $<5 \mu \mathrm{M}$ in resting state and about $10-15 \mu \mathrm{M}$ post-prandial. However, in case of liver or pancreatic diseases, BAs concentrations can increase to around $300 \mu \mathrm{M}[48,49]$. In normal bile, the concentration of bile acids is higher than $100 \mathrm{mM}$, and CDCA contributes to about $50 \%$ [50]. Therefore, pancreas could be exposed to low BA concentrations as well as to higher concentrations resulting from bile reflux into pancreatic duct tree following outflow obstruction, e.g., gallstones. In the current studies, we used concentrations that have been considered stimulatory on pancreatic ducts $[27,28]$.

The most important finding is that primary bile acids can cause ATP release and therefore stimulate purinergic signalling in exocrine pancreatic cells. The unconjugated CDCA had the most pronounced effects compared to far less effective glycine- and taurine-conjugated forms of the acid (Fig. 1). Thus CDCA caused fast and large ATP release from both acinar and duct cells (Fig. 1). In comparison, cholinergic or hormonal stimulation or cell swelling of pancreatic cells induced significantly lower ATP release [34, 35]. We investigated the mechanisms of ATP release and find that both exocytotic pathways and ion channels/receptors seemed to be involved in this process (Fig. 2b, c). Our findings with bafilomycin, brefeldin and NEM strongly support participation of a vesicular component in ATP release, e.g., VNUT (Fig. 2b), which is also expressed in duct cells (unpublished data). In addition, the inhibitor data (Fig. 2C) indicate that connexin hemichannels and/or pannexin with P2X7R could also be involved in ATP release. One of the most potent blockers was $\mathrm{Gd}^{3+}$ that can inhibit pannexin/connexins, $\mathrm{Ca}^{2+}$ influx and hence exocytosis, and it is known inhibitor of maxi-anion channels which may be a part of osmosensitive ATP release with hypotonic stress $[51,52]$. We cannot exclude that CDCA either can activate these maxi-anion channels directly or it induce cell volume changes, though cell volume changes due to hypotonic shock (unpublished data) have much smaller impact on ATP release than CDCA. The P2X7 receptors may also have positive effects on CDCA-induced ATP release (Fig. 2c), and modulating effects of the receptor on exocytosis and/or pannexin-1 have been described in other cells $[53,54]$. CFTR has also been proposed as a channel/regulator for ATP release [36] and in bile ducts the secondary ursodeoxycholic acid stimulates CFTRdependent ATP secretion [43]. In Capan-1 cells, CFTR does not seem to contribute to ATP release (unpublished 

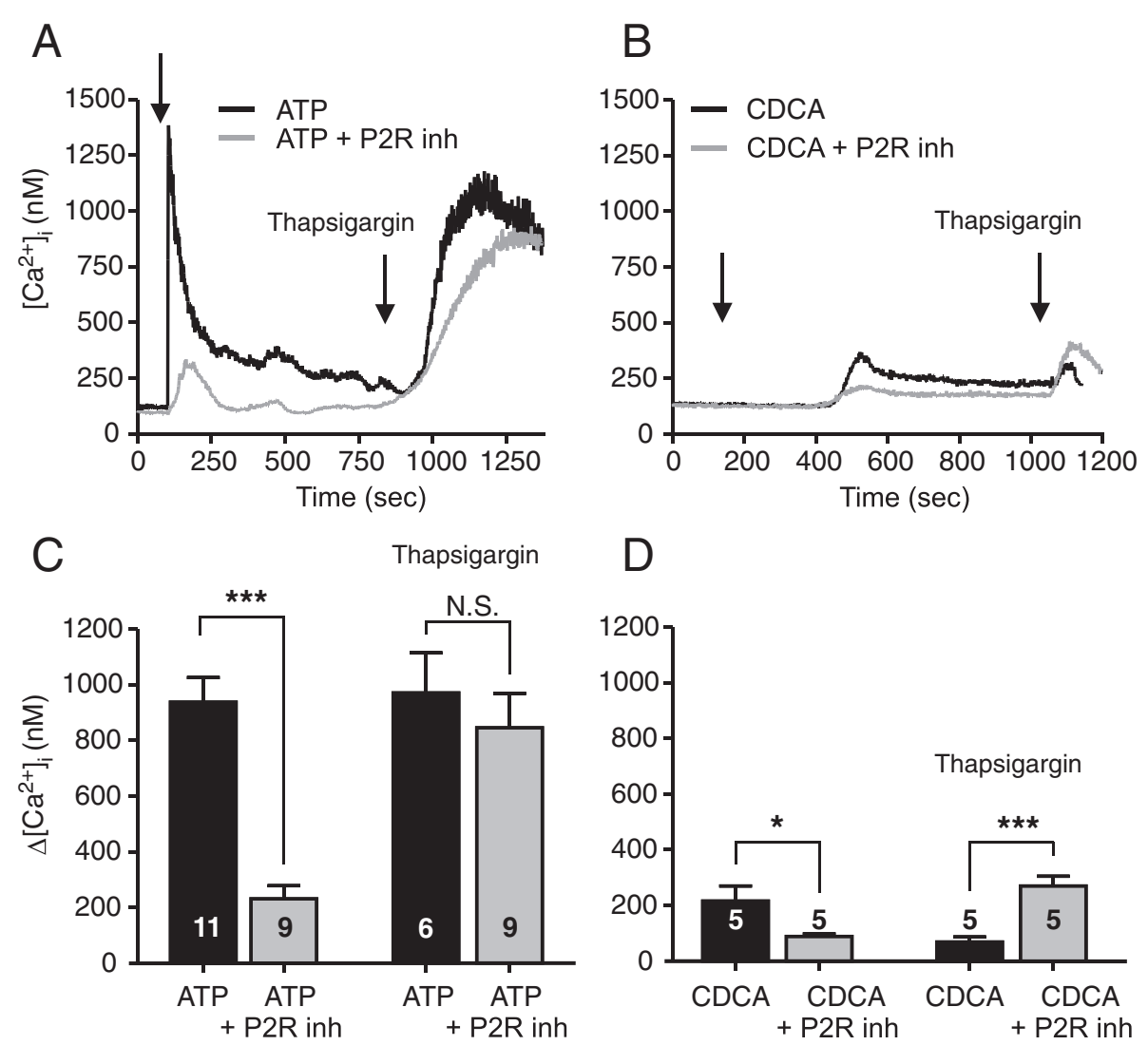

Fig. 7 Effect of $\mathrm{P} 2$ receptor inhibitors on intracellular $\mathrm{Ca}^{2+}$ responses induced by CDCA in Capan-1 cells. $\mathbf{a}$ and $\mathbf{b}$ Representative recordings of $\left[\mathrm{Ca}^{2+}\right]_{\mathrm{i}}$ transients in Capan-1 cells with or without P2 receptors inhibitors (standing bath). Cell were incubated with a mix of P2R inhibitors: PPADS $(250 \mu \mathrm{M})$, suramin $(250 \mu \mathrm{M})$, and $10 \mu \mathrm{M}$ of AZ 10606120 and $10 \mu \mathrm{M}$ of A438079 for $25 \mathrm{~min}$. a, c The presence of P2R antagonists markedly inhibited $\left[\mathrm{Ca}^{2+}\right]_{\mathrm{i}}$ response induced by ATP $(100 \mu \mathrm{M})$, but had no effect on Thapsigargin $(1 \mu \mathrm{M})$ induced Ca ${ }^{2+}$ response. $\mathbf{b}$, $\mathbf{d}$ Incubation cells with P2R antagonists inhibited $\left[\mathrm{Ca}^{2+}\right]_{i}$ transient induced by $0.3 \mathrm{mM}$ CDCA but not by Thapsigargin $(1 \mu \mathrm{M}) . \mathbf{c}, \mathbf{d}$ Change in $\left[\mathrm{Ca}^{2+}\right]_{i}$ above baseline are given as mean values \pm SEM of 7-15 cells per each independent experiment ( $n$ ). Arrows indicate the time of adding the stimuli. ${ }^{*}=P<0.05,{ }^{* * *}=P<0.001, N . S=$ not significant

data). Taken together, we propose that several ATP releasing mechanism contribute to CDCA-evoked ATP release, and result in extracellular ATP increase by $100-$ 1000 fold, which is the largest increase compared to that observed with other stimuli (unpublished data).

One important point to consider was how the BAinduced ATP release is triggered. Since GPBAR-A and GW4046 had no effects on ATP release, we presume that the TGR5 and FXR receptors are not involved. An alternative mechanism could be BA induced membrane depolarisation [21], which may be mediated by activation of bile acid-sensitive ion channel (BASIC), which belongs to the DEG/ENaC family, recently identified in bile ducts [55]. In addition, CDCA may incorporate into membranes, increase membrane fluidity [56] and thereby affect one or more of ATP release mechanisms as proposed above. Nevertheless, we show that the ATP release is clearly directed towards the lumen of pancreatic ducts (Fig. 2a), and therefore it is likely that there is a trigger mechanism and luminal exocytosis/transport mechanisms.
Also in other epithelia, e.g., kidney tubuli and airway epithelia, ATP is released preferentially to the apical/luminal side in response to a number of stimuli [57-60].

Regarding effect of BA in pancreas, we propose that BA stimulates release of ATP towards lumen and then ATP binds to P2 receptors and therefore stimulates $\mathrm{Ca}^{2+}$ signalling pathways, and these can potentially increase $\mathrm{Cl}^{-}$and $\mathrm{K}^{+}$conductances, which are necessary to initiate and acid/base transport and thus ductal fluid secretion. Indeed it is well documented that several P2 receptors regulate ion channels such as TMEM16A/ANO1, CFTR and $\mathrm{K}_{\mathrm{Ca}} 3.1$ and $\mathrm{K}_{\mathrm{Ca}} 1.1[32,61]$. The more traditional view is that BAs acting directly on BA receptors can affect epithelial transport [10, 26, 62]. For example, in airway epithelial cells, taurodeoxycholic acid (TDCA) stimulates CFTR and $\mathrm{Ca}^{2+}$-activated $\mathrm{Cl}^{-}$currents and these effects seems to be mediated by the basolateral TGR5 receptor [10]. From published studies on pancreatic duct epithelia, it was not clear whether BA receptors were expressed. Nevertheless, it is reported that in dog 


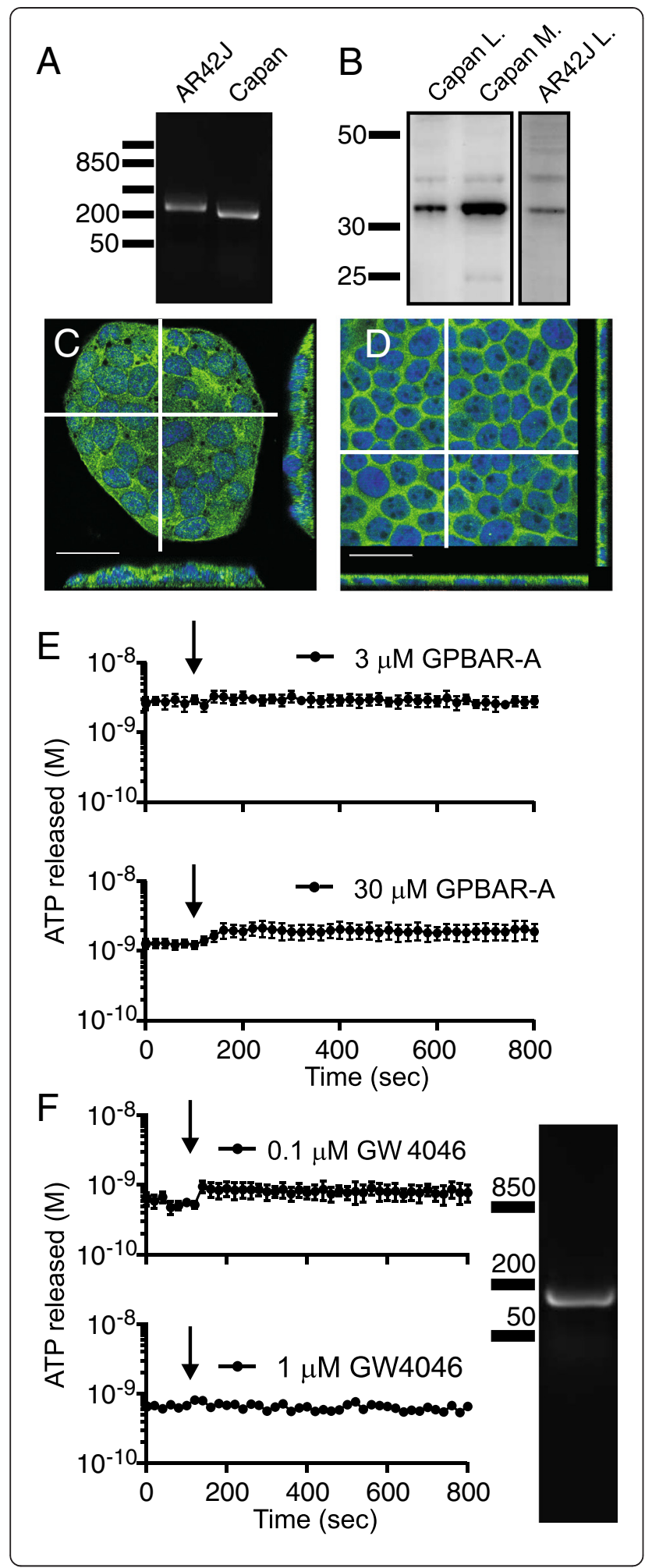

Fig. 8 TGR5 and FXR receptors expression in exocrine pancreatic cells. a RT-PCR and $\mathbf{b}$ Western Blot analysis of the TGR5 receptor expression in AR42J and Capan-1 cells, in lysates $(L)$ and membrane microdomain enriched fraction (M) shows a clear band at $33 \mathrm{kDa}$. c - d Immunocytochemistry of TGR5 in AR2J and Capan-1 cells. Scale bars are $25 \mu \mathrm{m}$. White lines indicate where the $z$ scan was taken. e. The effect of the TGR5 receptor agonist GPBAR-A at 3 and $30 \mu \mathrm{M}$ $(n=3,4)$ on ATP release from Capan- 1 cells. $\mathbf{f}$ Expression of FXR in Capan-1 cells showed by RT-PCR. Activation of FXR with the specific agonist GW4046 at 0.1 and $1 \mu M(n=3,2)$ did not have effect on ATP release from duct cells. Arrows indicate when the agonists were added

pancreatic duct epithelial cells TDCA also increased $\mathrm{Cl}^{-}$ and $\mathrm{K}^{+}$fluxes [26], and in guinea pig pancreatic ducts BAs stimulate $\mathrm{K}_{\mathrm{Ca}} 1.1$ channels, but accompanying $\mathrm{Cl}^{-}$ channels have not been detected $[27,30]$.

Previous studies show that CDCA $(0.5 \mathrm{mM})$ caused ATP depletion in pancreatic acinar cells and colon epithelial cells, presumed to be due to inhibited metabolism $[63,64]$. Since CDCA induced such a large ATP release in our exocrine cells (Fig. 1), it was relevant to examine whether CDCA could also affect intracellular ATP. We have used several techniques to study this, including intracellular ATP sensors. The transient increase in MgGreen fluorescence could indicate transient decrease in ATP $\mathrm{A}_{\mathrm{i}}$. However, since CDCA and ATP caused transient increase in $\left[\mathrm{Ca}^{2+}\right]_{\mathrm{i}}$, and the fluorophore can also bind $\mathrm{Ca}^{2+}$, the MgGreen signals can have several components. In addition, in AR42J cells there was a slow increase in MgGreen fluorescence occurring long after $\mathrm{Ca}^{2+}$ peak. There was a similar slow effect of CDCA on AT1.03 ${ }^{\text {YEMK }}$ ratio, as well as a change in the lifetime constants of the sensor. These data together indicate that there was a decrease in $\mathrm{ATP}_{\mathrm{i}}$. Using luciferase assay, we find that in the first minute after CDCA stimulation acinar cells release significant amount of cellular ATP (Fig. 5c), though $\mathrm{ATP}_{\mathrm{i}}$ seems to decrease first after 12 min, as also indicated by the AT1.03 ${ }^{\text {YEMK }}$ measurements (Fig. 4). Nevertheless, it is only after long-term incubation of AR42J cells with $0.5 \mathrm{mM}$ CDCA that significant depletion in $\mathrm{ATP}_{\mathrm{i}}$ was detected by luminescence assay (Fig. 5c). This depletion could be due to decreased mitochondrial ATP production and/or secondary effects caused by digestive enzymes released by CDCAinduced exocytosis $[20,63,65]$ and by exocytosis/release of ATP, as we show in the present study. In contrast to acini, pancreatic ducts seem very robust. In duct cells, CDCA caused release of less than $3 \%$ of total intracellular ATP, and ATP was presumably replenished (Fig. 5b), which also agrees with total recovery of MgGreen fluorescence with continued CDCA stimulation. Interestingly, in pancreatic islets, BAs (e.g., tauroursodeoxycholate) are not detrimental but enhance $\mathrm{ATP}_{\mathrm{i}}$ concentration [15].

It is extensively documented that BAs $(0.1-1 \mathrm{mM})$ cause an increase in $\left[\mathrm{Ca}^{2+}\right]_{\mathrm{i}}$ in many cells, including 

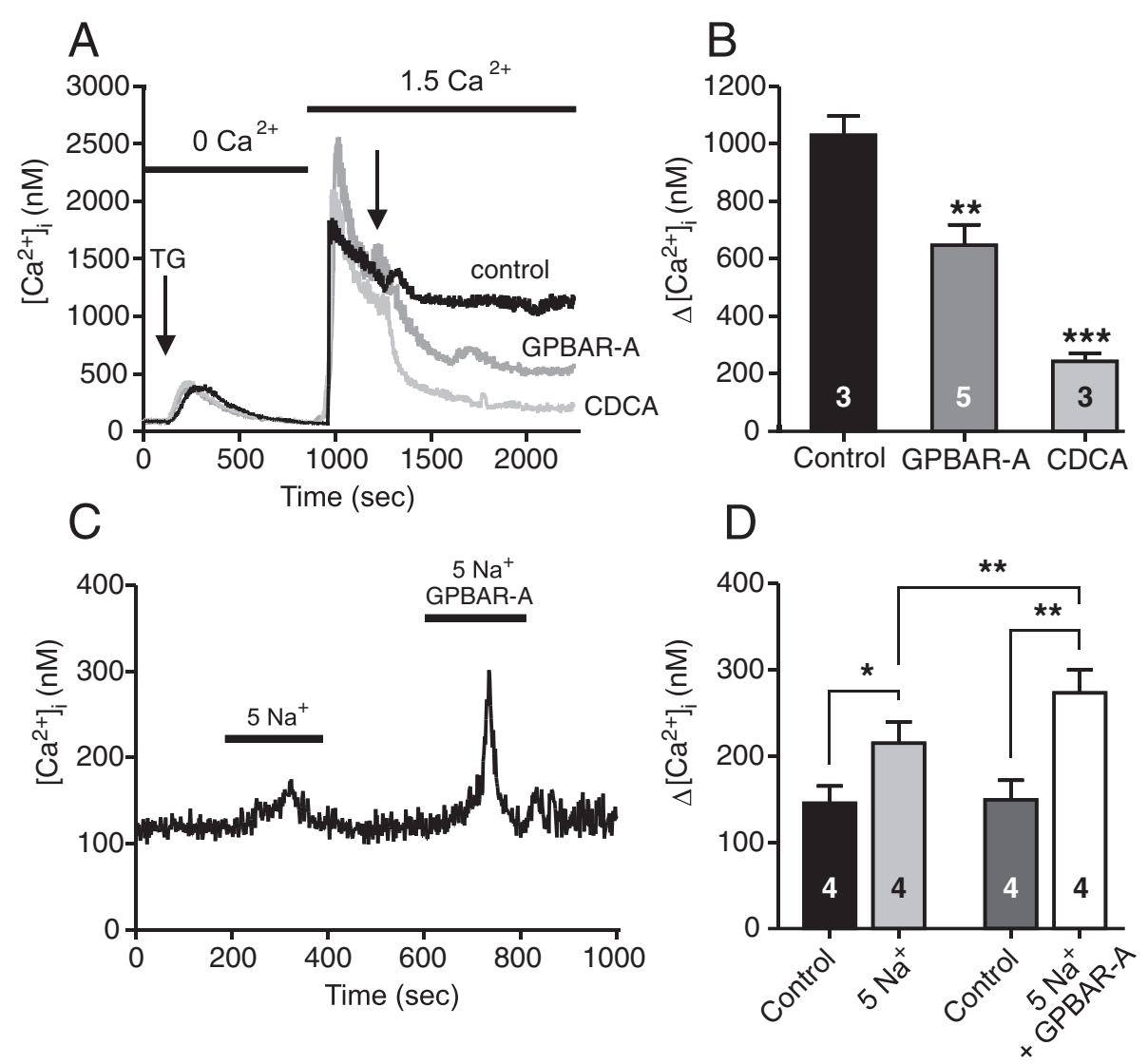

Fig. 9 Effect of the TGR5 ligands on $\left[\mathrm{Ca}^{2+}\right]_{i}$ transients in duct epithelia. Capan-1 cells were incubated with nominal 0 mM Ca ${ }^{2+}$ buffer $(\mathbf{a}$, b) and thapsigargin $(1 \mu \mathrm{M})$ to deplete intracellular $\mathrm{Ca}^{2+}$ stores. Thereafter, cells were gently perfused with physiological buffer to refill intracellular $\mathrm{Ca}^{2+}$ stores and after the fluorescence was relatively stable, solutions were changed to GPBAR-A (30 $\mu \mathrm{M})$, CDCA (0.3 mM), or control. $\mathbf{c}$, $\mathbf{d}$ The contribution of the sodium-calcium exchanger (NCX) was tested. Cells were perfused with $5 \mathrm{mM} \mathrm{Na}^{+}$buffer which increased $\left[\mathrm{Ca}^{2+}\right]_{i}$ and this response was potentiated in the presence of GPBAR-A $(30 \mu \mathrm{M})$. $\mathbf{b}$, $\mathbf{d}$ Summary of data given as mean values \pm SEM of 7-15 cells per each independent experiment (n). ${ }^{*}=P<0.05,{ }^{* * *}=P<0.001$, N.S $=$ not significant

pancreatic cells and mechanisms include increased release from ER, inhibition of SERCA and increased $\mathrm{Ca}^{2+}$ entry $[20,21,27,66]$. Regarding TGR5, it is well established that the receptor interacts with $\mathrm{G}_{\mathrm{s}}$ protein and leads to stimulation of adenylate cyclase and cAMP signalling $[5,12,45,67]$. In addition, several reports show that BAs (high $\mu \mathrm{M}$ concentrations) show small and slow increases in intracellular $\mathrm{Ca}^{2+}[10,18,21,23,25,45]$. Underlying mechanisms are unclear, as seen in a number of studies, though one study has suggested the involvement of TGR5 [10, 18, 21, 23, 25, 45]. In pancreatic acinar cells genetic deletion of TRG5 still leaves BA-induced $\mathrm{Ca}^{2+}$ transients in many cells and BA-stimulated amylase release is relatively undisturbed [25], indicating that there is not very tight coupling between TGR5 and $\mathrm{Ca}^{2+}$ signalling. Since GPBAR-A had no effect on $\left[\mathrm{Ca}^{2+}\right]_{i}$ in our duct cells expressing the receptor, it seems that TGR5 receptor is not involved in initiating simple $\mathrm{Ca}^{2+}$ transients in given experimental conditions. We propose that CDCA-evoked ATP release leads to P2 receptor activation and thereby increases in $\left[\mathrm{Ca}^{2+}\right]_{\mathrm{i}}$. Indeed, CDCAstimulated $\mathrm{Ca}^{2+}$ increase was inhibited by a cocktail of P2R antagonists (Fig. 7d). This observation indicates that a significant part of $\mathrm{Ca}^{2+}$-dependent $\mathrm{BA}$ effects could be due to ATP release and subsequent stimulation of P2 receptors expressed in duct cells. These processes and potential effects on ion transport are acute (seconds to minutes). Our study did not address the question whether BAs via activation of FXR and TGR5 could regulate purinergic receptor expression on a longer time-scale.

The differences in the thapsigargin induced $\mathrm{Ca}^{2+}$ response after stimulation with ATP or CDCA lead us to speculate whether there is a possible protective role of CDCA during high $\left[\mathrm{Ca}^{2+}\right]_{\mathrm{i}}$ stress conditions in pancreas. It has been shown that CDCA can protect cells when ER is depleted of $\mathrm{Ca}^{2+}[68]$. We observed that CDCA markedly decreased the thapsigargin-induced high $\left[\mathrm{Ca}^{2+}\right]_{\mathrm{i}}$ and 
that the GPBAR-A was similarly effective (Fig. 9a). Others have shown that bile acids could prevent thapsigargin-evoked ER stress in liver, adipocytes and $\beta$ cells $[15,69]$. Our observations are in the line with these and we suggest that the "protective effect" of CDCA is mediated via TGR5 activation. Pancreatic ducts express NCX, which is stimulated by cAMP and $\mathrm{Ca}^{2+}$ [47]. We propose that some of the CDCA-induced decrease in high $\left[\mathrm{Ca}^{2+}\right]_{\mathrm{i}}$ conditions could be due to NCX activation. Indeed stimulation of TGR5 with GPBAR-A increased NCX activity (Fig. 9c). It should be noted that since NCX is electrogenic (exchanging $1 \mathrm{Ca}^{2+}: 3 \mathrm{Na}^{+}$), it can transport $\mathrm{Ca}^{2+}$ in or out of the cell, depending in electrochemical potential, and this could vary depending on the cell type and its stimulation.

\section{Conclusions}

In conclusion, as summarized in Fig. 10, the most important finding in our study is that unconjugated BA evokes significant ATP release from pancreatic exocrine cells, this ATP in turn can stimulate P2R, which thereby increases $\left[\mathrm{Ca}^{2+}\right]_{\mathrm{i}}$. We show the expression of the TGR5 receptor in a human duct cell line, where it could play a protective role at high intracellular $\mathrm{Ca}^{2+}$ conditions.
Taken together, for pancreas we envisage that purinergic signalling is a significant part of the cellular response to BA and could support the physiological function such as secretion. Finally, we propose that purinergic signalling, i.e., ATP release and cell/organ P2 receptor involvement, should be taken into consideration in other cell/organ types, as it could potentially explain the multifaceted and ubiquitous effects of BAs.

\section{Methods}

\section{Chemicals}

All chemicals were purchased from Sigma-Aldrich unless otherwise specified. In present study following chemicals were used: chenodeoxycholic acid (CDCA sodium salt, $0.1-1 \mathrm{mM}$ ), glycochenodeoxycholic acid (GCDCA sodium salt, 0.3 and $1 \mathrm{mM}$ ), taurochenodeoxycholic acids (TCDCA sodium salt, 0.3 and $1 \mathrm{mM})$, ATP $(100 \mu \mathrm{M})$, digitonin $(50 \mu \mathrm{M})$, thapsigargin $(1 \mu \mathrm{M}), 4-[[3,5$-Bis (trifluoromethyl)phenyl]methyl]-6-(2-fluorophenyl)-4,5dihydro-pyrido[3,2-f]-1,4-oxazepin-3(2H)-one (GPBARA, $30 \mu \mathrm{M}$, Tocris) dexamethasone $(50 \mathrm{nM})$. Cells were pre-treated/incubated with inhibitors and fluorescent indicators as follow: bafilomycin A1 $(1 \mu \mathrm{M})$, N-Ethyl maleimide (NEM, $250 \mu \mathrm{M})$, brefeldin A $(5 \mu \mathrm{g} / \mathrm{ml}$;

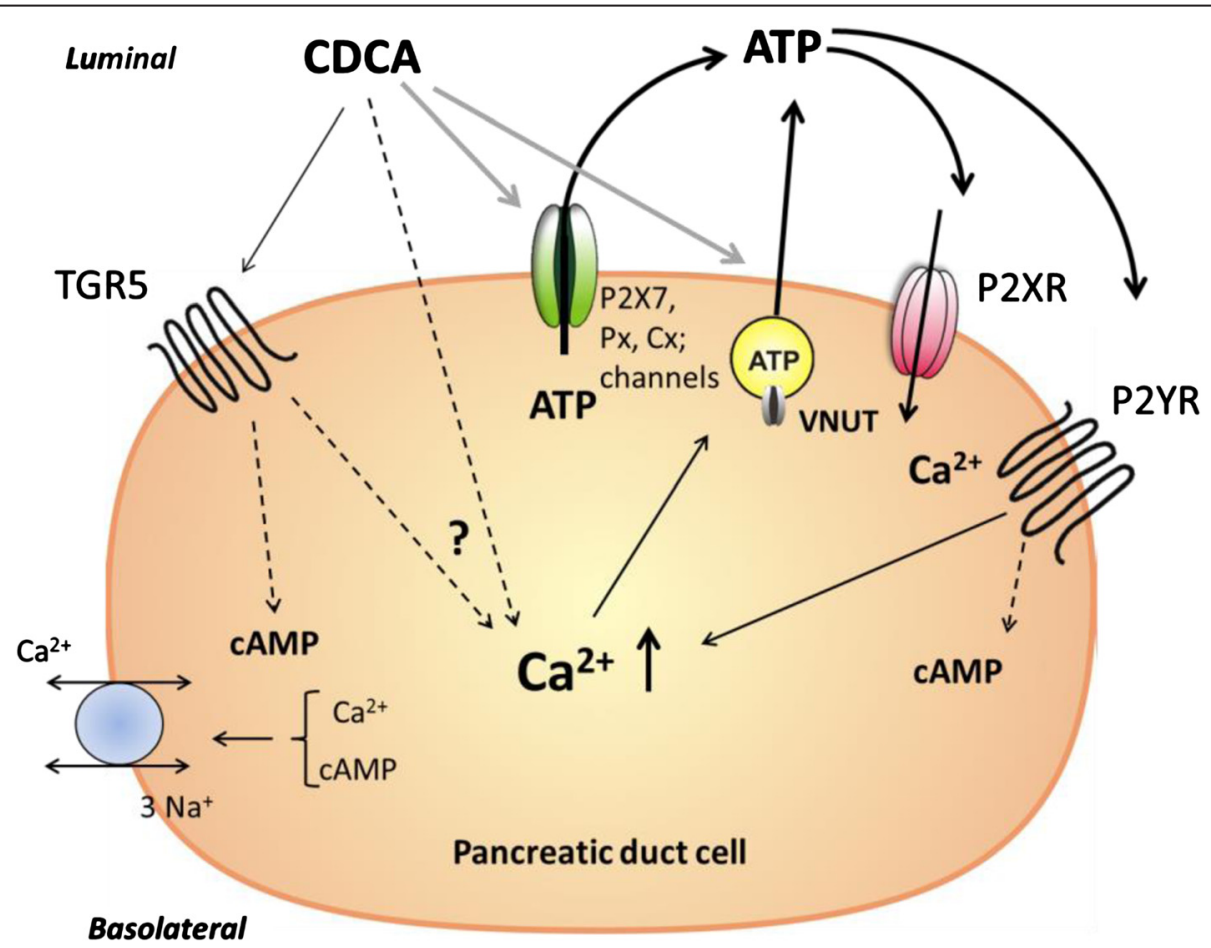

Fig. 10 Proposed model of CDCA-induced cellular responses in pancreatic duct cells. CDCA acting on the plasma cell membrane induces ATP release via non-vesicular releasing mechanisms (pannexin, connexin, P2X7R, other ion channels) and vesicular exocytosis of ATP. Released ATP may in turn activate P2X receptors/cation channels and P2Y receptors, which allow $\mathrm{Ca}^{2+}$ influx directly (P2XR) or via G-protein coupled signalling mediate $\mathrm{Ca}^{2+}$ release from intracellular stores and $\mathrm{Ca}^{2+}$ influx (P2YR). Furthermore, CDCA may activate TGR5 receptor, which leads to stimulation of adenylyl cyclase and cAMP production, possibly increase in $\mathrm{Ca}^{2+}$ in some cells by yet undefined mechanisms. The sodium-calcium exchanger (NCX) can be stimulated by TGR5 resulting of transport of $\mathrm{Ca}^{2+}$ out of the cell, or into the cell, depending on prevailing electrochemical gradients 
Molecular Probes- Life Technology), pannexin inhibitor ${ }^{10}$ Panx $\left(100 \mu \mathrm{M}\right.$, Tocris), gadolinium chloride $\left(\mathrm{Gd}^{3+}\right.$, $50 \mu \mathrm{M})$, probenecid $(500 \mu \mathrm{M})$, P2X7 inhibitors: AZ10606120 $(10 \mu \mathrm{M}$, Tocris $)$ and A438079 $(10 \mu \mathrm{M}$, Tocris), pyridoxal phosphate-6-azo(benzene-2,4-disulfonic acid) tetrasodium salt hydrate (PPADS, $250 \mu \mathrm{M}$ ), suramin $250 \mu \mathrm{M}$, Magnesium Green indicator (MgGreen; $5 \mu \mathrm{M}$, Invitrogen), Fura-2 AM calcium indicator ( $5 \mu \mathrm{M}$, Teflabs), pluronic F127 (Molecular Probes- Life Technology), ATP kit SL 144-041 (BioThema), cell counting kit-8 (CCK-8, DOJINDO).

\section{Cell cultures}

Pancreatic rat acinar (AR42J, CRL-1492) and human duct (Capan-1, HTB-79) cell lines were obtained from ATTC (Manassas, VA) and cultured according to recommended procedures. For imaging experiments WillCodishes (WillCo Wells BV, Amsterdam, the Netherlands) were used and for luminescence, 96-well NUNC white plates. For luminescence recordings of ATP release, 50,000 Capan-1 cells were cultured to $80 \%$ confluence and for imaging 35.000 cells were cultured for 2 days. For all experiments for AR42J, 10,000 cells (or 40,000 cells for FRET-FLIM analysis) were plated and grown for $48 \mathrm{~h}$, followed by $48 \mathrm{~h}$ with $50 \mathrm{nM}$ dexamethasone to induce an acinar phenotype, which increases formation of zymogen granules [70]. All experiments were conducted at $37^{\circ} \mathrm{C}$.

\section{Measurement of ATP concentrations}

Different protocols were used to measure ATP: in extracellular fluid; in single cells; permeabilized cells and polarized cells. Extracellular ATP $\left(\mathrm{ATP}_{\mathrm{e}}\right)$ was monitored in using luciferase + luciferin luminescence reaction in extracellular medium. Capan-1 and AR42J cells were washed and allowed to rest in $65 \mu \mathrm{l}$ of physiological buffer that contained (in $\mathrm{mM}$ ): $140 \mathrm{NaCl}, 1 \mathrm{MgCl}_{2} \cdot 6 \mathrm{H}_{2} \mathrm{O}$, $1.5 \mathrm{CaCl}_{2}, 0.4 \mathrm{KH}_{2} \mathrm{PO}_{4}, 1.6 \mathrm{~K}_{2} \mathrm{HPO}_{4} \cdot 3 \mathrm{H}_{2} \mathrm{O}, 10 \mathrm{HEPES}$ and 20 glucose (Capan-1) or 10 glucose (AR42J); $\mathrm{pH}=$ 7.4. After $30 \mathrm{~min}, 25 \mu \mathrm{l}$ of $2 \times$ concentrated luciferase/ luciferin mix was added into the wells. Measurements were made using plate mode (20-s sampling rate with 1-s integration) in FLUOstar Optima (BMG, Labtech). CDCA $(10 \mu \mathrm{l})$ was gently added manually. To quantify CDCA-induced intracellular ATP $\left(\mathrm{ATP}_{\mathrm{i}}\right)$, similar protocol was repeated but after $1 \mathrm{~min}$ of recordings, cells were permeabilized with $25 \mu \mathrm{l}$ of digitonin $(50 \mu \mathrm{M})$. For each experimental protocol, standard curves were made with ATP concentrations $10^{-9}$ to $10^{-5} \mathrm{M}$. The bile acids were included in all standards. Also the effect of the inhibitors on luciferase/luciferine was tested independently on standard curves (Additional file 1: Figure S2 a-b). Cell number was determined by cell counting kit and ATP concentrations were corrected for $10^{6}$ cells per $1 \mathrm{ml}$. To calculate the single cell $\mathrm{ATP}_{\mathrm{i}}$ concentration, volumes of Capan-1 and AR42J were estimated assuming a spherical shape with diameter of $12 \mu \mathrm{m}$ and $10 \mu \mathrm{m}$, respectively.

To investigate the polarity of ATP release, i.e., to the luminal or basolateral sides of polarized epithelium, 200,000-400,000 Capan-1 cells $/ \mathrm{cm}^{2}$ were seeded on collagen-coated Snapwells (no. 3407; Corning). When resistance of the monolayer was $\sim 500-600 \Omega_{n} \mathrm{~cm}^{2}$, Snapwells were put into a holder, and monolayers were incubated with $500 \mu \mathrm{l}$ of physiological solution on each side (luminal and basolateral). $150 \mu \mathrm{l}$ of fluid was collected for a baseline value, and cells were then luminally or basolaterally stimulated with $0.3 \mathrm{mM} \mathrm{CDCA} .150 \mu \mathrm{l}$ samples collected from apical and basolateral sides and heated for $1 \mathrm{~min}$ in $98{ }^{\circ} \mathrm{C}$ and kept on ice before analysed for ATP.

\section{Magnesium-Green fluorescence measurement}

$\mathrm{ATP}_{\mathrm{i}}$ was estimated indirectly using Magnesium Green (MgGreen) fluorescence. Cells were incubated with $5 \mu \mathrm{M}$ MgGreen in presence of $0.02 \%$ pluronic F127 for $20 \mathrm{~min}$ and gently washed $15 \mathrm{~min}$ before experiments. MgGreen was excited with an argon laser $(488 \mathrm{~nm})$ and emission was monitored at $498-581 \mathrm{~nm}$ using a confocal laser scanning microscope (TCS SP 5X, Leica Microsystems, Heidelberg). Images were captured every $3 \mathrm{sec}$ using a 20X N.A. 0.7 immersion (water) objective. Images analysis was performed on 10 single cells or group of AR42J per dish. Changes of $\mathrm{ATP}_{\mathrm{i}}$ responses are presented as ratios at time $t$ in relation to time $0\left(\mathrm{~F}_{\mathrm{t}} / \mathrm{F}_{0}\right)$ and baseline is set to 1 .

\section{ATP sensor FRET-FLIM microscopy}

ATP $_{i}$ was estimated more specifically using FRET sensor based on $\varepsilon$ subunit of bacterial F0F1-synthase, i.e., AT1.03 ${ }^{\text {YEMK }}$ [41]. AR42J cells were transfected using FuGENE transfection kit (Promega) according to manufacturer's protocol. Media was changed the day after transfection to media containing dexametasome. Experiments were conducted on AR42J cells bathed in physiological saline containing $10 \mathrm{mM}$ glucose and the temperature was $37^{\circ} \mathrm{C}$ and images were collected with a $63 \mathrm{x}$ water objective (HCX PLAPO, 1.2 NA) in a TCS SP5X Confocal microscope). Two types of recordings were made: FRET ratio analysis and FRET-FLIM analysis. In time resolved protocols, $405 \mathrm{~nm}$ laser was used for excitation of the CFP, the fluorescence of CFP and excited YFP was collected simultaneously at $460-500 \mathrm{~nm}$ for CFP and 530-570 nm for YFP. Images were taken at $3 \mathrm{~s}$ intervals. The individual measurements were corrected for background and YFP/CFP ratio was continuously recorded. In separate experiments, FRET was estimated using fluorescence lifetime imaging (FLIM). The SP5X microscope, equipped with a time-correlated single-photon counting 
(TCSPC) module (PicoHarp 300, PicoQuant, Berlin, Germany), allows FLIM analysis using a Mai-Tai TiSapphire laser $(850 \mathrm{~nm})$ providing $80 \mathrm{ps}$ pulses. The CFP lifetime was recorded with the emission filter: $450-500 \mathrm{~nm}$ and detected by FLIM PMT. The laser power was reduced so the counting was kept under 800 kcounts to avoid build up effects. Photons were collected continuously for $2 \mathrm{~min}$ for each image. The decay curve was analysed with the SymProTime software (PicoQuant) via a tail-fitting procedure. The counts around the peak were typically around $10^{3}$ photons and the quality of the fit was judged on the basis of the chisquared statistic, $\chi^{2}$, and reduced randomness of residuals. Three to five different positions in each dish with cells were analysed before and after addition of CDCA.

\section{Calcium signals}

Capan-1 cells were incubated with Fura-2 AM in the presence of $0.02 \%$ pluronic F127 and probenecid $(0.25 \mathrm{mM})$ in physiological buffer for $30 \mathrm{~min}$. For perfusion experiments the perfusion rate was $1 \mathrm{ml} / \mathrm{min}$. For standing bath (non-perfused) conditions cells were incubated for $25 \mathrm{~min}$ with or without P2R antagonists. In some experiments, Capan-1 cells were stimulated with Thapsigargin in nominal $\mathrm{Ca}^{2+}$-free buffer containing (in $\mathrm{mM}$ ): $115 \mathrm{NaCl}, 25 \mathrm{Na}$-gluconate, $1 \mathrm{MgCl}_{2} \cdot 6 \mathrm{H}_{2} \mathrm{O}, 5$ HEPES, $1.6 \mathrm{~K}_{2} \mathrm{HPO}_{4} \cdot 3 \mathrm{H}_{2} \mathrm{O}, 0.4 \mathrm{KH}_{2} \mathrm{PO}_{4}, 20$ glucose, 5 EGTA. Subsequently, cells were gently perfused with buffer containing $\mathrm{Ca}^{2+}$ and after 6-8 min cells were perfused with physiological buffer including CDCA or GPBAR-A. In order to examine the role of the sodiumcalcium exchanger (NCX) on $\left[\mathrm{Ca}^{2+}\right]_{\mathrm{i}}$ changes, Capan-1 cells were perfused with $5 \mathrm{mM} \mathrm{Na}^{+}$buffer, where the rest of $\mathrm{NaCl}$ was substituted with $140 \mathrm{~N}$-Methyl-D-Glucamine (NMDG) titrated with $\mathrm{HCl}$. Fura-2 recording was performed on a system described earlier [71]. Fura2 ratios were calibrated in situ to calcium concentrations based on formula described by Grynkiewicz [72] with $\mathrm{K}_{\mathrm{d}}$ for Fura-2: 224 nM.

\section{Reverse transcription PCR}

RNA was isolated using RNeasy Mini Kit (Qiangen 74104) following the manufacturer's instructions. RTPCR was analysed with QIAGEN OneStep RT-PCR Kit (210212) with amplification parameters as follows: one cycle at $50{ }^{\circ} \mathrm{C}$ for $30 \mathrm{~min}$ and one cycle at $95{ }^{\circ} \mathrm{C}$ for 15 min followed by 37 cycles at $95{ }^{\circ} \mathrm{C}$ for $30 \mathrm{~s}, 58^{\circ} \mathrm{C}$ for $30 \mathrm{~s}, 72{ }^{\circ} \mathrm{C}$ for $40 \mathrm{~s}$, and one final cycle at $72{ }^{\circ} \mathrm{C}$ for $10 \mathrm{~min}$. The following primers were designed using Primer BLAST and used for TGR5 amplification: human TGR5 forward 3' TCCTGCCTCCTCGTCTACTT 5' human TGR5 reverse 3' GGTAGGGGGCTGGGAAG ATA 5'(247 bp), human FXR forward 3'AGAGATGGG AATGTTGGCTGAA 5' human FXR reverse 3' GTGA
GTTCAGTTTTCTCCCTG 5'(186 bp), rat TGR5 forward 3' GCTACTGGAGTGGTAGGCAG 5' rat TGR5 reverse 3' TCAGTCTTGGCCTATGAGCG 5'(225 bp). All primers were synthesised by TAG Copenhagen A/S (Denmark).

\section{Western blot}

Protein lysates were prepared by adding lysis buffer (50 mM TrisBase, $0.25 \mathrm{M} \mathrm{NaCl}, 5 \mathrm{mM}$ EDTA, $1 \%$ Triton $\mathrm{X}-100$, and $4 \mathrm{mM} \mathrm{NaF}$ ) containing protease inhibitor. Cell lysates were centrifuged at $15,000 \mathrm{~g}$ for $15 \mathrm{~min}$ at $4{ }^{\circ} \mathrm{C}$. To obtain the membrane microdomain enriched samples the lysate was centrifuged at 200,000 g for $1 \mathrm{~h}$ (Beckman Ultracentrifuge Ti 70.1 Rotor) [61]. Western blot samples were denatured by heating to $37^{\circ} \mathrm{C}$ in $50 \mathrm{mM}$ dithiothreitol for $30 \mathrm{~min}$ and run on precast gels from Invitrogen. The membranes were blocked overnight at $4{ }^{\circ} \mathrm{C}$ in $0.5 \%$ milk powder and $1 \%$ BSA. Primary antibody for TGR5 (1:400 rabbit, Abcam ab72608) were added in blocking buffer for $1.5 \mathrm{~h}$. The goat anti-rabbit secondary antibody conjugated to horse-radish peroxidase $(1: 2.500)$ was added in blocking buffer, for $1 \mathrm{~h}$. EZ-ECL chemiluminescence detection kit for HRP (BI, Biological Industries) was added and blots were viewed on Fusion FX Vilber Lourmat.

\section{Immunocytochemistry}

AR42J cells were grown on glass coverslips (similar as for dishes, see above) and Capan-1 cells were seeded on collagen coated Snapwells. The cells were gently washed with physiological PBS and fixed in $4 \%$ paraformaldehyde in PBS for $15 \mathrm{~min}$, treated with $0.1 \mathrm{M}$ TRIS-glycine ( $\mathrm{pH}$ 7.4) for $15 \mathrm{~min}$, and then rinsed in PBS and permeabilized for $10 \mathrm{~min}$ in PBS with $0.5 \%$ TritonX-100. Cells were blocked with $10 \%$ BSA in PBS for 45 min and then incubated with TGR5 (1:400; Abcam) for $1.5 \mathrm{~h}$. Slides were washed for $10 \mathrm{~min}$ and then incubated $1 \mathrm{~h}$ with 1:400 goat anti-rabbit secondary antibody conjugated to Alexa 488 (Life Technology). For nuclear staining, DAPI was used (1:400) and mounted with DAKO fluorescent mounting medium. Slides were viewed using a 40X N.A 1.3 objective with TCS SP $5 \mathrm{X}$.

\section{Statistics}

Data are shown as the mean values \pm S.E.M. To test the statistical significance between two conditions, unpaired two-tail Student's $t$ test was applied. For multiple conditions, one-way ANOVA with Bonferroni's Multiple Comparison Test was used. $P<0.05$ was considered statistically significant. For FLIM-FRET analysis and statistics see above. 


\section{Additional file}

Additional file 1: Figure S1. Effect of GPBAR-A on intracellular $\mathrm{Ca}^{2+}$ response from Capan-1 cells. Figure S2. Effect of (A) CDCA and (B) ATP release inhibitors on standard curves.

\section{Abbreviations}

ATP : Intracellular Adenosine 5' - triphosphate; ATP : Extracellular Adenosine 5' - triphosphate; BA(s): Bile acid(s); CDCA: Chenodeoxycholic acid; GCDCA: Glycochenodeoxycholic acid; CFTR: Cystic fibrosis transmembrane conductance regulator; $\left[\mathrm{Ca}^{2+}\right]_{i}:$ Intracellular $\mathrm{Ca}^{2+}$ concentration; FLIM: Fluorescence lifetime imaging; FRET: Fluorescence resonance energy transfer; FXR: Farnesoid X receptor; GPBAR-A: 4-[[3,5-Bis(trifluoromethyl) phenyl]methyl]-6-(2-fluorophenyl)-4,5-dihydro-pyrido[3,2-f]-1,4-oxazepin-3 $(2 \mathrm{H})$-one; MgGreen: Magnesium Green indicator; NCX: Sodium/calcium exchanger; NEM: N-Ethylmaleimide; P2R: P2 purinergic receptor; PPADS: Pyridoxal phosphate-6-azo(benzene-2,4-disulfonic acid) tetrasodium salt hydrate; SERCA: Sacro/endoplasmatic reticulum $\mathrm{Ca}^{2+}$ ATPases; TCDCA: Taurochenodeoxycholic acid; TGR5: G protein-coupled bile acid receptor; VNUT: Vesicular NUcleotide Transporter.

\section{Competing interests}

The authors declare that they have no competing interests.

\section{Author contribution}

The study was planned by IN, JMK, KAH and NMC. JMK performed all experiments and analysis on Capan-1 cells. KAH performed experiments on AR42J cells. NMC and IN performed experiments on ATP sensor. IN concept of the study. The manuscript was written by JMK and IN. All authors were involved in critically revising and approved the final version of the manuscript.

\section{Acknowledgements}

ATP sensor was kindly provided by Professor Hiromi Imamura, Japan Science and Technology Agency. Imaging experiments were done in the Center for Advanced Bioimaging (CAB), University of Copenhagen, Denmark. The technical assistance of Pernille Roshof is greatly acknowledged.

\section{Author details}

'Department of Biology, Section for Cell Biology and Physiology, August Krogh Building, University of Copenhagen, Universitetsparken 13, DK-2100 Copenhagen, Denmark. ${ }^{2}$ Present address: Department of Clinical Experimental Research, Glostrup Research Institute, Copenhagen University Hospital, Glostrup, Denmark.

\section{Received: 28 January 2015 Accepted: 26 May 2015} Published online: 09 June 2015

\section{References}

1. Kawamata Y, Fujii R, Hosoya M, Harada M, Yoshida H, Miwa M, et al. A G protein-coupled receptor responsive to bile acids. J Biol Chem. 2003:278:9435-40.

2. Makishima M, Okamoto AY, Repa JJ, Tu H, Learned RM, Luk A, et al. Identification of a nuclear receptor for bile acids. Science. 1999;284:1362-5.

3. Maruyama T, Miyamoto Y, Nakamura T, Tamai Y, Okada H, Sugiyama E, et al. Identification of membrane-type receptor for bile acids (M-BAR). Biochem Biophys Res Commun. 2002;298:714-9.

4. Schaap FG, Trauner M, Jansen PL. Bile acid receptors as targets for drug development. Nat Rev Gastroenterol Hepatol. 2014;11:55-67.

5. Maruyama T, Tanaka K, Suzuki J, Miyoshi H, Harada N, Nakamura T, et al. Targeted disruption of G protein-coupled bile acid receptor 1 (Gpbar1/M-Bar) in mice. J Endocrinol. 2006;191:197-205.

6. Watanabe M, Houten SM, Mataki C, Christoffolete MA, Kim BW, Sato H, et al. Bile acids induce energy expenditure by promoting intracellular thyroid hormone activation. Nature. 2006;439:484-9.

7. Pols TW, Noriega LG, Nomura M, Auwerx J, Schoonjans K. The bile acid membrane receptor TGR5 as an emerging target in metabolism and inflammation. J Hepatol. 2011;54:1263-72.

8. Keely SJ, Scharl MM, Bertelsen LS, Hagey LR, Barrett KE, Hofmann AF. Bile acid-induced secretion in polarized monolayers of T84 colonic epithelial cells: Structure-activity relationships. Am J Physiol Gastrointest Liver Physiol. 2007;292:G290-7.

9. Mroz MS, Keating N, Ward JB, Sarker R, Amu S, Aviello G, et al. Farnesoid X receptor agonists attenuate colonic epithelial secretory function and prevent experimental diarrhoea in vivo. Gut. 2014;63:808-17.

10. Hendrick SM, Mroz MS, Greene CM, Keely SJ, Harvey BJ. Bile acids stimulate chloride secretion through CFTR and calcium-activated $\mathrm{Cl}^{-}$channels in Calu-3 airway epithelial cells. Am J Physiol Lung Cell Mol Physiol. 2014;307:L407-18.

11. Keitel V, Gorg B, Bidmon HJ, Zemtsova I, Spomer L, Zilles K, et al. The bile acid receptor TGR5 (Gpbar-1) acts as a neurosteroid receptor in brain. Glia. 2010;58:1794-805.

12. Masyuk Al, Huang BQ, Radtke BN, Gajdos GB, Splinter PL, Masyuk TV, et al. Ciliary subcellular localization of TGR5 determines the cholangiocyte functional response to bile acid signaling. Am J Physiol Gastrointest Liver Physiol. 2013;304:G1013-24.

13. Beuers $U$, Hohenester $S$, de Buy Wenniger $L$, Kremer $A E$, Jansen $P L$, Elferink RP. The biliary $\mathrm{HCO}_{3}^{-}$umbrella: a unifying hypothesis on pathogenetic and therapeutic aspects of fibrosing cholangiopathies. Hepatology. 2010;52:1489-96.

14. Keitel V, Haussinger D. TGR5 in cholangiocytes. Curr Opin Gastroenterol. 2013;29:299-304.

15. Lee $Y Y$, Hong SH, Lee $Y$ J, Chung SS, Jung HS, Park SG, et al. Tauroursodeoxycholate (TUDCA), chemical chaperone, enhances function of islets by reducing ER stress. Biochem Biophys Res Commun. 2010;397:735-9.

16. Dufer M, Horth K, Wagner R, Schittenhelm B, Prowald S, Wagner TF, et al. Bile acids acutely stimulate insulin secretion of mouse beta-cells via farnesoid $X$ receptor activation and $K_{\text {ATP }}$ channel inhibition. Diabetes. 2012;61:1479-89.

17. Kumar DP, Rajagopal S, Mahavadi S, Mirshahi F, Grider JR, Murthy KS, et al. Activation of transmembrane bile acid receptor TGR5 stimulates insulin secretion in pancreatic beta cells. Biochem Biophys Res Commun. 2012;427:600-5.

18. Thomas C, Gioiello A, Noriega L, Strehle A, Oury J, Rizzo G, et al. TGR5-mediated bile acid sensing controls glucose homeostasis. Cell Metab. 2009;10:167-77.

19. Meloni AR, DeYoung MB, Lowe C, Parkes DG. GLP-1 receptor activated insulin secretion from pancreatic beta-cells: mechanism and glucose dependence. Diabetes Obes Metab. 2013;15:15-27.

20. Kim JY, Kim KH, Lee JA, Namkung W, Sun AQ, Ananthanarayanan M, et al. Transporter-mediated bile acid uptake causes Ca2 + -dependent cell death in rat pancreatic acinar cells. Gastroenterology. 2002;122:1941-53.

21. Voronina SG, Gryshchenko OV, Gerasimenko OV, Green AK, Petersen OH, Tepikin AV. Bile acids induce a cationic current, depolarizing pancreatic acinar cells and increasing the intracellular $\mathrm{Na}^{+}$concentration. J Biol Chem. 2005;280:1764-70

22. Petersen $\mathrm{OH}$, Sutton R. $\mathrm{Ca}^{2+}$ signalling and pancreatitis: effects of alcohol, bile and coffee. Trends Pharmacol Sci. 2006;27:113-20.

23. Gerasimenko JV, Flowerdew SE, Voronina SG, Sukhomlin TK, Tepikin AV, Petersen $\mathrm{OH}$, et al. Bile acids induce $\mathrm{Ca}^{2+}$ release from both the endoplasmic reticulum and acidic intracellular calcium stores through activation of inositol trisphosphate receptors and ryanodine receptors. J Biol Chem. 2006;281:40154-63.

24. Wan MH, Huang W, Latawiec D, Jiang K, Booth DM, Elliott V, et al. Review of experimental animal models of biliary acute pancreatitis and recent advances in basic research. HPB (Oxford). 2012;14:73-81.

25. Perides $\mathrm{G}$, Laukkarinen JM, Vassileva G, Steer ML. Biliary acute pancreatitis in mice is mediated by the G-protein-coupled cell surface bile acid receptor Gpbar1. Gastroenterology. 2010;138:715-25.

26. Okolo C, Wong T, Moody MW, Nguyen TD. Effects of bile acids on dog pancreatic duct epithelial cell secretion and monolayer resistance. Am J Physiol Gastrointest Liver Physiol. 2002;283:G1042-50.

27. Venglovecz V, Rakonczay Jr Z, Ozsvari B, Takacs T, Lonovics J, Varro A, et al Effects of bile acids on pancreatic ductal bicarbonate secretion in guinea pig. Gut. 2008:57:1102-12.

28. Hegyi P, Petersen $\mathrm{OH}$. The exocrine pancreas: the acinar-ductal tango in physiology and pathophysiology. Rev Physiol Biochem Pharmacol. 2013;165:1-30.

29. Venglovecz V, Hegyi P, Rakonczay Jr Z, Tiszlavicz L, Nardi A, Grunnet M, et al. Pathophysiological relevance of apical large-conductance $\mathrm{Ca}^{2+}$-activated potassium channels in pancreatic duct epithelial cells. Gut. 2011;60:361-9. 
30. Ignath I, Hegyi P, Venglovecz V, Szekely CA, Carr G, Hasegawa M, et al. CFTR expression but not $\mathrm{Cl}^{-}$transport is involved in the stimulatory effect of bile acids on apical $\mathrm{Cl}^{-}$. Pancreas. 2009;38:921-9.

31. Burnstock G, Novak I. Purinergic signalling in the pancreas in health and disease. J Endocrinol. 2012;213:123-41.

32. Novak I, Haanes KA, Wang J. Acid-base transport in pancreas-new challenges. Front Physiol. 2013;4:380.

33. Haanes KA, Novak I. ATP storage and uptake by isolated pancreatic zymogen granules. Biochem J. 2010;429:303-11.

34. Haanes KA, Kowal JM, Arpino G, Lange SC, Moriyama Y, Pedersen PA, Novak I. Role of vesicular nucleotide transporter VNUT (SLC17A9) in release of ATP from AR42J cells and mouse pancreatic acinar cells. Purinergic Signal. 2014,

35. Sorensen CE, Novak I. Visualization of ATP release in pancreatic acini in response to cholinergic stimulus. Use of fluorescent probes and confocal microscopy. J Biol Chem. 2001;276:32925-32.

36. Lazarowski ER. Vesicular and conductive mechanisms of nucleotide release. Purinergic Signal. 2012;8:359-73.

37. Lohman AW, Isakson BE. Differentiating connexin hemichannels and pannexin channels in cellular ATP release. FEBS Lett. 2014;588:1379-88.

38. Yegutkin GG, Samburski SS, Jalkanen S, Novak I. ATP-consuming and ATP-generating enzymes secreted by pancreas. J Biol Chem. 2006;281:29441-7.

39. Okada SF, Nicholas RA, Kreda SM, Lazarowski ER, Boucher RC. Physiological regulation of ATP release at the apical surface of human airway epithelia. J Biol Chem. 2006;281:22992-3002.

40. Yegutkin GG, Mikhailov A, Samburski SS, Jalkanen S. The detection of micromolar pericellular ATP pool on lymphocyte surface by using lymphoid ecto-adenylate kinase as intrinsic ATP sensor. Mol Biol Cell. 2006;17:3378-85.

41. Imamura $H$, Nhat KP, Togawa $H$, Saito $K$, lino $R$, Kato-Yamada $Y$, et al. Visualization of ATP levels inside single living cells with fluorescence resonance energy transfer-based genetically encoded indicators. Proc Natl Acad Sci U S A. 2009;106:15651-6.

42. Becker W, Bergmann A, Hink MA, Konig K, Benndorf K, Biskup C. Fluorescence lifetime imaging by time-correlated single-photon counting. Microsc Res Tech. 2004;63:58-66.

43. Fiorotto R, Spirli C, Fabris L, Cadamuro M, Okolicsanyi L, Strazzabosco M. Ursodeoxycholic acid stimulates cholangiocyte fluid secretion in mice via CFTR-dependent ATP secretion. Gastroenterology. 2007;133:1603-13.

44. Thastrup O, Cullen PJ, Drobak BK, Hanley MR, Dawson AP. Thapsigargin, a tumor promoter, discharges intracellular $\mathrm{Ca}^{2+}$ stores by specific inhibition of the endoplasmic reticulum $\mathrm{Ca}^{2+}$-ATPase. Proc Natl Acad Sci U S A. 1990;87:2466-70.

45. Parker HE, Wallis K, le Roux CW, Wong KY, Reimann F, Gribble FM. Molecular mechanisms underlying bile acid-stimulated glucagon-like peptide-1 secretion. Br J Pharmacol. 2012;165:414-23.

46. Hansen MR, Krabbe S, Ankorina-Stark I, Novak I. Purinergic receptors stimulate $\mathrm{Na}^{+} / \mathrm{Ca}^{2+}$ exchange in pancreatic duct cells: possible role of proteins handling and transporting Ca ${ }^{2+}$. Cell Physiol Biochem. 2009;23:387-96.

47. Ankorina-Stark I, Amstrup J, Novak I. Regulation of the $\mathrm{Na}^{+} / \mathrm{Ca}^{2+}$ exchanger in rat pancreatic ducts. J Membr Biol. 2002;186:43-53.

48. Neale G, Lewis B, Weaver V, Panveliwalla D. Serum bile acids in liver disease. Gut. 1971;12:145-52.

49. Brufau G, Bahr MJ, Staels B, Claudel T, Ockenga J, Boker KH, et al. Plasma bile acids are not associated with energy metabolism in humans. Nutr Metab (Lond). 2010;7:73.

50. Fisher MM, Yousef IM. Sex differences in the bile acid composition of human bile: studies in patients with and without gallstones. Can Med Assoc J. 1973;109:190-3.

51. Liu HT, Toychiev AH, Takahashi N, Sabirov RZ, Okada Y. Maxi-anion channel as a candidate pathway for osmosensitive ATP release from mouse astrocytes in primary culture. Cell Res. 2008;18:558-65.

52. Sabirov RZ, Dutta AK, Okada Y. Volume-dependent ATP-conductive large-conductance anion channel as a pathway for swelling-induced ATP release. J Gen Physiol. 2001;118:251-66.

53. Gutierrez-Martin Y, Bustillo D, Gomez-Villafuertes R, Sanchez-Nogueiro J, Torregrosa-Hetland C, Binz T, et al. P2X7 receptors trigger ATP exocytosis and modify secretory vesicle dynamics in neuroblastoma cells. J Biol Chem. 2011;286:11370-81.

54. Pelegrin $P$, Surprenant $A$. The $P 2 X 7$ receptor-pannexin connection to dye uptake and IL-1beta release. Purinergic Signal. 2009;5:129-37.
55. Wiemuth D, Sahin H, Falkenburger BH, Lefevre CM, Wasmuth HE, Grunder S. BASIC-a bile acid-sensitive ion channel highly expressed in bile ducts. FASEB J. 2012;26:4122-30.

56. Schroder O, Rathner W, Caspary WF, Stein J. Bile acid-induced increase of rat colonic apical membrane fluidity and proton permeability. Z Gastroenterol. 1996;34:365-70.

57. Seminario-Vidal L, Kreda S, Jones L, O'Neal W, Trejo J, Boucher RC, et al. Thrombin promotes release of ATP from lung epithelial cells through coordinated activation of rho- and $\mathrm{Ca}^{2+}$-dependent signaling pathways. J Biol Chem. 2009;284:20638-48.

58. Wilson PD, Hovater JS, Casey CC, Fortenberry JA, Schwiebert EM. ATP release mechanisms in primary cultures of epithelia derived from the cysts of polycystic kidneys. J Am Soc Nephrol. 1999;10:218-29.

59. Bjaelde RG, Arnadottir SS, Overgaard MT, Leipziger J, Praetorius HA. Renal epithelial cells can release ATP by vesicular fusion. Front Physiol. 2013;4:238.

60. Praetorius HA, Leipziger J. Released nucleotides amplify the cilium-dependent, flow-induced [Ca2+]i response in MDCK cells. Acta Physiol (Oxf). 2009;197:241-51.

61. Wang J, Haanes KA, Novak I. Purinergic regulation of CFTR and $\mathrm{Ca}^{2+}$-activated $\mathrm{Cl}^{-}$channels and $\mathrm{K}^{+}$channels in human pancreatic duct epithelium. Am J Physiol Cell Physiol. 2013;304:C673-84.

62. Kelly OB, Mroz MS, Ward JB, Colliva C, Scharl M, Pellicciari R, et al. Ursodeoxycholic acid attenuates colonic epithelial secretory function. J Physiol. 2013;591:2307-18.

63. Voronina SG, Barrow SL, Simpson AW, Gerasimenko OV, da Silva X, Rutter GA, et al. Dynamic changes in cytosolic and mitochondrial ATP levels in pancreatic acinar cells. Gastroenterology. 2010;138:1976-87.

64. Ignacio BJ, Olmo N, Perez-Ramos P, Santiago-Gomez A, Lecona E, Turnay J, et al. Deoxycholic and chenodeoxycholic bile acids induce apoptosis via oxidative stress in human colon adenocarcinoma cells. Apoptosis. 2011;16:1054-67.

65. Duan RD, Erlanson-Albertsson C. Effect of bile salt on amylase release from rat pancreatic acini. Scand J Gastroenterol. 1985;20:1239-45.

66. Nguyen A, Bouscarel B. Bile acids and signal transduction: role in glucose homeostasis. Cell Signal. 2008;20:2180-97.

67. Keitel V, Reinehr R, Gatsios P, Rupprecht C, Gorg B, Selbach O, et al. The G-protein coupled bile salt receptor TGR5 is expressed in liver sinusoidal endothelial cells. Hepatology. 2007:45:695-704.

68. Xie Q, Khaoustov VI, Chung CC, Sohn J, Krishnan B, Lewis DE, et al. Effect of tauroursodeoxycholic acid on endoplasmic reticulum stress-induced caspase-12 activation. Hepatology. 2002;36:592-601.

69. Cummings BP, Bettaieb A, Graham JL, Kim J, Ma F, Shibata N, et al. Bile-acid-mediated decrease in endoplasmic reticulum stress: a potential contributor to the metabolic benefits of ileal interposition surgery in UCD-T2DM rats. Dis Model Mech. 2013;6:443-56.

70. Logsdon CD, Moessner J, Williams JA, Goldfine ID. Glucocorticoids increase amylase mRNA levels, secretory organelles, and secretion in pancreatic acinar AR42J cells. J Cell Biol. 1985;100:1200-8.

71. Hansen MR, Krabbe S, Novak I. Purinergic receptors and calcium signalling in human pancreatic duct cell lines. Cell Physiol Biochem. 2008;22:157-68.

72. Grynkiewicz G, Poenie M, Tsien RY. A new generation of $\mathrm{Ca}^{2+}$ indicators with greatly improved fluorescence properties. J Biol Chem. 1985;260:3440-50.

\section{Submit your next manuscript to BioMed Central and take full advantage of:}

- Convenient online submission

- Thorough peer review

- No space constraints or color figure charges

- Immediate publication on acceptance

- Inclusion in PubMed, CAS, Scopus and Google Scholar

- Research which is freely available for redistribution 